\title{
VERIFICATION OF VENTSAR
}

A. A. Simpkins

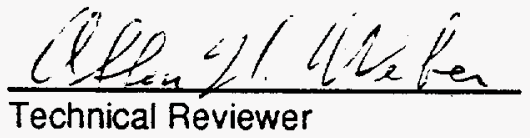

January 1995

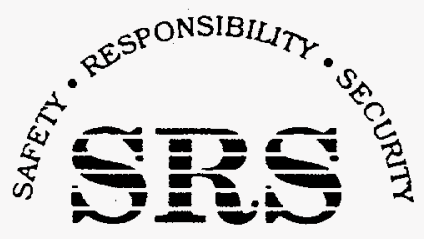

SAVANNAH RIVER SITE

PREPARED FOR THE U.S. DEPARTMENT OF ENERGY UNDER CONTRACT NO. DE-ACO9-8\$SR18035 


\section{DISCLAIMER}

This report was prepared as an account of work sponsored by an agency of the United States Government. Neither the United States Government nor any agency thereof, nor any of their employees, makes any warranty, express or implied, or assumes any legal liability or responsibility for the accuracy, completeness, or usefulness of any information, apparatus, product, or process disclosed, or represents that its use would not infringe privately owned rights. Reference herein to any specific commercial product, process, or service by trade name, trademark, manufacturer, or otherwise does not necessarily constitute or imply endorsement, recommendation, or favoring by the United States Government or any agency thereof. The views and opinions of authors expressed herein do not necessarily state or reflect those of the United States Government or any agency thereof. 


\section{DISCLAIMER}

Portions of this document may be illegible in electronic image products. Images are produced from the best available original document. 
Key Words

Source Terms

Atmospheric Dispersion

Building Wake Effects

Retention: Lifetime

\title{
VERIFICATION OF VENTSAR
}

\author{
A. A. Simpkins
}

Issued: January 1995

SRTC

SAVANNAH RIVER TECHNOLOGY CENTER

AIKEN, SC 29808

Westinghouse Savannah River Company

Savannah River Site

Alken, SC 29808

PREPARED FOR THE U.S. DEPARTMENT OF ENERGY UNDER CONTRACT NO. DE-AC09-89SR18035 


\section{ABSTRACT}

VENTSAR is a computer model that will analyze flow patterns of pollutants on or near buildings. Plume rise may be considered. Verification of VENTSAR is complete and the methodology is discussed in detail within this report. Hand calculations were performed to ensure proper application of methodologies. 


\section{TABLE OF CONTENTS}

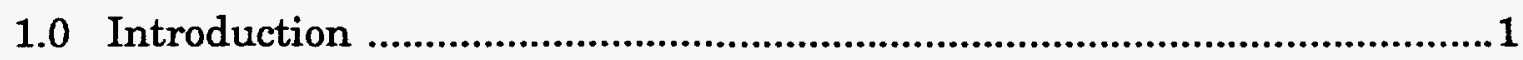

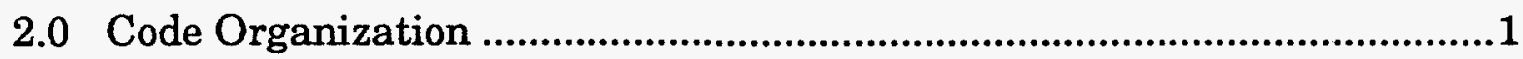

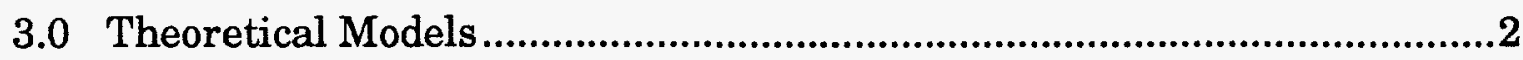

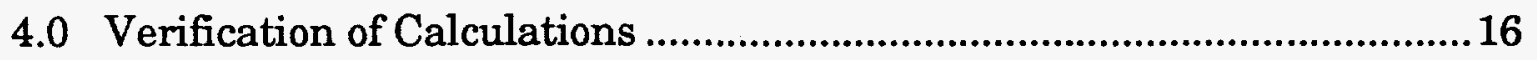

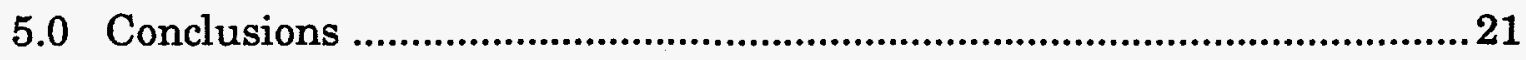

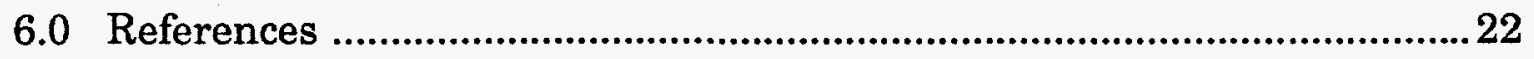

Appendix A. Hand Calculations ….................................................................23 


\section{LIST OF TABLES}

Table 1. Wind Speed Category Ranges ...........................................................4

Table 2. Classification of Atmospheric Stability ..............................................4

Table 3. Brigg's Vertical Diffusion Coefficient Formulas .................................5

Table 4. Input parameters for Plume Rise Verification..................................17

Table 5. Hand Calculations for Plume Rise Verification ...............................17

Table 6. Input parameters for Building Wake Effects Verification. .............. 18

Table 7. Hand Calculations for Building Wake Effects Verification...............19

Table 8. Input parameters for Building Wake Effects and PR Ver. ..............19

Table 9. Hand Calculations for Building Wake Effects and PR Ver.............20

Table 10. Input parameters for Averaging Option..........................................20

Table 11. Hand Calculations for Averaging Option Verification ...................21

Table 12. Hand Calculations for Annual Average Concentration...................21

\section{LIST OF FIGURES}

Figure 1. Subroutine Layout ............................................................. 2

Figure 2. Recirculation Zones for Building Wake Effects Calculations....... 12

Figure 3. Dimensions of Building and Penthouse used with VENTSAR 13

Figure 4. Concentration locations for Building Wake Effects Verification 18 


\title{
VERIFICATION OF VENTSAR
}

\author{
A. A. Simpkins \\ Westinghouse Savannah River Company \\ Savannah River Technology Center \\ Aiken, SC 29808
}

\subsection{INTRODUCTION}

The VENTSAR code is an upgraded and improved version of the VENTX code (Smith and Weber, 1983), which estimates concentrations on or near a building from a release at a nearby location. The code calculates the concentrations either for a given meteorological exceedance probability or for a given stability and wind speed combination. A single building can be modeled which lies in the path of the plume, or a penthouse can be added to the top of the building. Plume rise may also be considered. Release types can be either chemical or radioactive. Downwind concentrations are determined at user-specified incremental distances.

This verification report was prepared to demonstrate that VENTSAR is properly executing all algorithms and transferring data. Hand calculations were also performed to ensure proper application of methodologies.

\subsection{CODE ORGANIZATION}

The code is set up so that the bulk of the work concerning the plume rise and building wake effects is done within the main program; however subroutines are called for other calculations. Figure 1 shows the layout of the subroutines used within VENTSAR; a brief description of each of the subroutines follows.

INPUT This subroutine reads the user input, checks the input for validity, and echoes it for the output. Unit conversions are also done as needed. The DRAW subroutines depicts the building dimension as a printer sketch in part of the output.

METDAT This subroutine reads the meteorological frequency distribution of the tower that is closest to the release point, if needed. The wind speeds are also read from this subroutine. The meteorological frequency distribution is echoed as part of the output.

STAB This subroutine determines the horizontal and vertical diffusion coefficients used to determine the relative air concentrations. 
CALCZ Determines the height of the plume based on the turbulence zones created by the building.

SORTER Ranks the relative air concentrations to determine the given probability value. The associated wind speed and stability class are also maintained.

Figure 1. Subroutine Layout

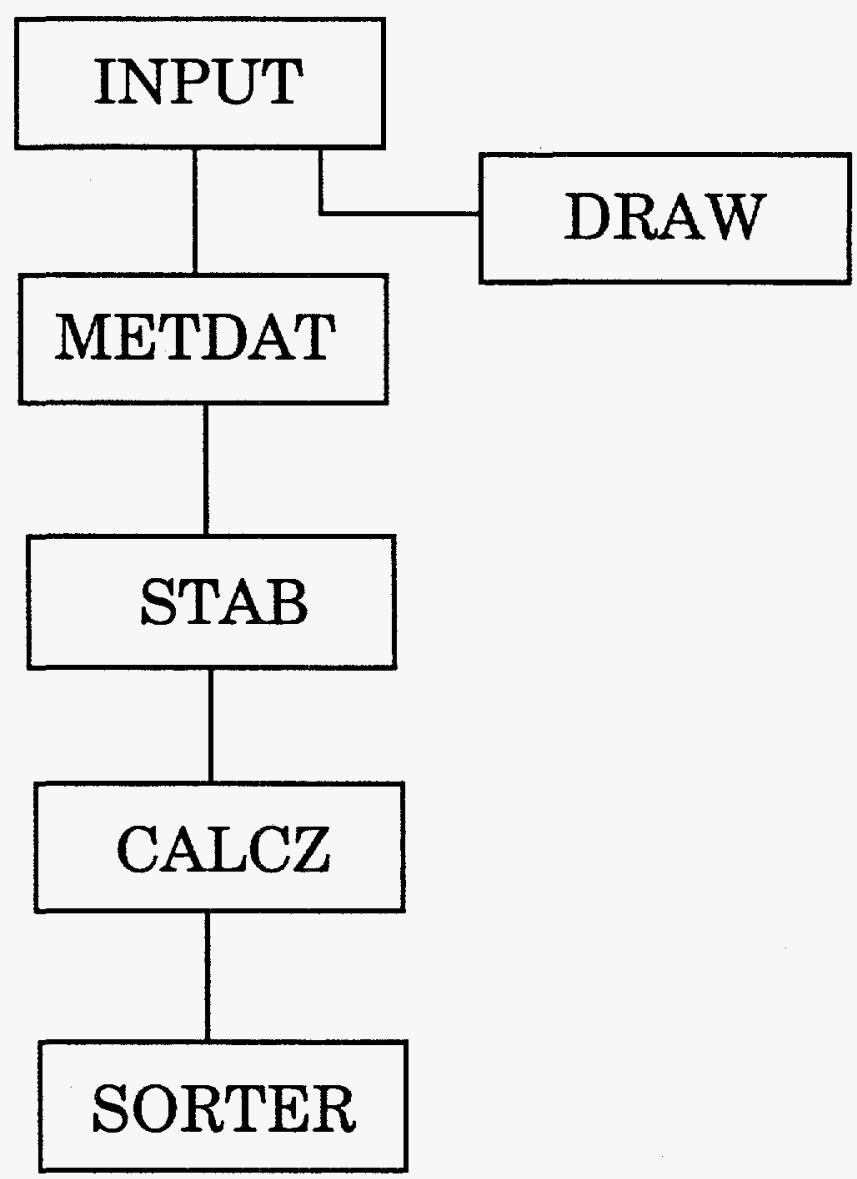

\subsection{THEORETICAL MODELS}

This section discusses the theoretical models and data files that are employed within VENTSAR. 


\subsection{Gaussian Plume Model}

The pollutant dispersion calculations in the VENTSAR code are based on a reflecting Gaussian plume model (Pasquill, 1961). Along the plume centerline, the dispersion factor or relative air concentration, defined as the ratio of the pollutant concentration $\chi\left(\mathrm{kg} / \mathrm{m}^{3}\right.$ or $\left.\mathrm{Ci} / \mathrm{m}^{3}\right)$ to the source strength $\mathrm{Q}(\mathrm{kg} / \mathrm{sec}$ or $\mathrm{Ci} / \mathrm{sec})$, is given by the equation:

$$
\frac{\chi}{Q}=\frac{1}{2 \pi \sigma_{y} \sigma_{z} U_{S}}\left[e^{-\left(\frac{\left(z-h_{s}\right)^{2}}{2 \sigma_{z}^{2}}\right)}+e^{-\left(\frac{\left(z+h_{y}\right)^{2}}{2 \sigma_{s}^{2}}\right)}\right]
$$

where:

$\chi / Q \quad$ the dispersion factor, $\left(\mathrm{sec} / \mathrm{m}^{3}\right)$;

$z \quad$ height above the ground surface, $(\mathrm{m})$;

$h_{e} \quad$ effective release height, $(\mathrm{m})$;

$U_{S} \quad$ wind speed at the release height, $(\mathrm{m} / \mathrm{sec})$;

$\sigma_{y}$ the standard deviation of the concentration distribution in the horizontal cross-plume direction, (m); and

$\sigma_{z}$ the standard deviation of the concentration distribution in the vertical direction, $(\mathrm{m})$.

Annual averaged values of $\chi / Q$ are calculated as:

$$
\operatorname{annual}(\chi \mid Q)=\sum P_{i}\left(\frac{\chi}{Q}\right)_{i}
$$

where

$(\chi / Q)_{i} \quad$ the value calculated for a specific meteorological condition, and

$\mathrm{P}_{\mathrm{i}}$ the probability of that particular meteorological condition occurring within a five-year time period.

\subsubsection{Meteorological Data Files}

Meteorological data files for use with VENTSAR exist for the following areas onsite: A, C, D, F, H, K, and P. The meteorological data are obtained from hourly averages of measurements made at 1.5 seconds intervals. The files contain joint frequency distributions and reciprocal average wind velocities 
categorized by wind direction, speed, and stability class. Reciprocal average wind speeds are utilized since air concentration is inversely proportional to wind speed. Table 1 provides wind speed category definitions. Validation of the meteorological data are the responsibility of the Environmental Transport Group. See Parker (1992) and Weber (1993) for more details on the wind statistics obtained from the SRS area meteorological towers.

Table 1. Wind Speed Category Ranges

\begin{tabular}{|c|c|}
\hline $\begin{array}{c}\text { Speed } \\
\text { Category }\end{array}$ & $\begin{array}{c}\text { Range } \\
\text { (m/sec) }\end{array}$ \\
\hline 1 & $0<\mathrm{U} \leq 2$ \\
2 & $2<\mathrm{U} \leq 4$ \\
3 & $4<\mathrm{U} \leq 6$ \\
4 & $6<\mathrm{U} \leq 8$ \\
5 & $8<\mathrm{U} \leq 12$ \\
6 & $\mathrm{U} \geq 12$ \\
\hline
\end{tabular}

Atmospheric stability is classified by standard deviations of the lateral or azimuthal wind direction. Area meteorological towers contain

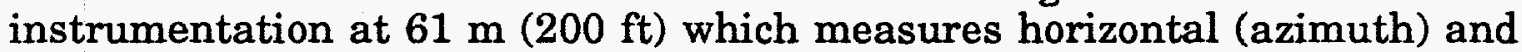
vertical (elevation) wind direction as well as direct measurements of turbulence, expressed as standard deviations of fluctuations about mean azimuth (noted either as $\sigma_{a}$ or $\sigma_{\theta}$ ) and elevation $\left(\sigma_{e}\right)$ angles.

For calculational purposes within the program, an assumed average value of $\sigma_{\theta}$ is chosen for the atmospheric stability class of interest as shown in Garrett and Hoel (1982). Ranges for $\sigma_{\theta}$ and the values that are used within VENTSAR are shown in Table 2.

Table 2. Classification of Atmospheric Stability

\begin{tabular}{|c|c|c|}
\hline $\begin{array}{c}\text { Pasquill } \\
\text { Category }\end{array}$ & $\begin{array}{c}\text { Range for } \sigma_{\theta} \\
\text { (degrees) }\end{array}$ & $\begin{array}{c}\sigma_{\theta} \text { Used in } \\
\text { VENTSAR } \\
\text { (degrees) }\end{array}$ \\
\hline A & $23 \leq \sigma_{\theta}$ & 27.5 \\
B & $18 \leq \sigma_{\theta}<23$ & 22.5 \\
C & $13 \leq \sigma_{\theta}<18$ & 17.5 \\
D & $8 \leq \sigma_{\theta}<13$ & 12.5 \\
E & $4 \leq \sigma_{\theta}<8$ & 7.5 \\
F & $2 \leq \sigma_{\theta}<4$ & 3.75 \\
G & $\sigma_{\theta}<2$ & 2.00 \\
\hline
\end{tabular}




\subsubsection{Pasquill-Briggs Dispersion Coefficients}

The lateral and vertical dispersion coefficients within VENTSAR are those derived by Pasquill (1976) and Briggs (1973), respectively. The equation representing Pasquill's lateral dispersion coefficients is shown below:

$$
\sigma_{y}=\sigma_{\theta} X f(X)
$$

where

$\sigma_{\theta} \quad$ standard deviation of lateral wind direction, (radians). See Table 2.

$X \quad$ downwind distance $(\mathrm{km})$, and

$f(X)$ function of distance, $X$ in kilometers, as discussed below.

Pasquill developed formulations for $f(X)$ with a table of values for distances less than $10 \mathrm{~km}$ and the following equation for distances greater than $10 \mathrm{~km}$ :

$$
f(X)=0.33\left[\frac{10}{X}\right]^{0.5}
$$

For distances less than $10 \mathrm{~km}$, the following equation was derived from the table of values with $X$ in kilometers:

$$
f(x)=\frac{1}{1+0.031(1000 X)^{0.46}}
$$

Pasquill (1976) gave a detailed description on how the coefficients were developed using data from experiments at various sites.

The vertical diffusion coefficients defined by Briggs (1973) and then refined by Briggs and published in Hanna (1982) for open-country conditions are represented in Table 3 as a function of Pasquill's atmospheric stability classes. For these equations the units of $X$ should be meters.

Table 3. Brigg's Vertical Diffusion Coefficient Formulas

\begin{tabular}{|c|l|}
\hline $\begin{array}{c}\text { Pasquill Stability } \\
\text { Category }\end{array}$ & \multicolumn{1}{|c|}{$\sigma_{\mathrm{z}}(\mathrm{X}$ in meters $)$} \\
\hline A & $0.20 X$ \\
B & $0.12 X$ \\
C & $0.08 X(1+0.0002 X)^{-0.5}$ \\
D & $0.06 X(1+0.0015 X)^{-0.5}$ \\
E & $0.03 X(1+0.0003 X)^{-1}$ \\
F & $0.02 X(1+0.0003 X)^{-1}$ \\
G & $0.01 X(1+0.0003 X)^{-1}$ \\
\hline
\end{tabular}




\subsection{Plume Rise}

Plume rise models are based on fundamental laws of fluid mechanics, conservation of mass, potential density, and momentum. The quantities across the plume are referred to as "top-hat" meaning that discontinuities in temperature, speed and etc. are assumed at the plume boundary. Therefore, for the models employed here, constant values are assumed inside the plume, and another constant value outside of the plume. VENTSAR considers plume rise due to both buoyancy and momentum effects.

Several different mechanisms can increase or decrease the height of the plume at downwind distances. Plume rise due to momentum and buoyancy effects can increase the height of the plume while downwash can decrease the height of the plume. The effective plume height at a given distance, $X$, downwind is:

$h(X)=h_{s}-\Delta h_{D}+\Delta h_{B}(X)+\Delta h_{M}(X)$

where

$h_{s} \quad$ initial height of the source,

$\Delta h_{D} \quad$ source height change due to downwash,

$\Delta h_{B} \quad$ source height change due to buoyancy effects, and

$\Delta h_{M} \quad$ source height change due to momentum effects.

\subsubsection{Downwash}

Downwash occurs when the plume is drawn downward due to low pressure in the wake of the stack. Downwash will not occur if the velocity of the effluent $\left(W_{e}\right)$ is a significantly greater than the crosswind velocity $(U)$. Downwash is generally recognized to occur when $W_{e} / U$ is less than 1.5 (Briggs, 1973). When the ratio is less than 1.5 the following equation is applied to determine the effects of downwash (Hanna, 1982):

$$
\Delta h_{D}=2\left(\frac{W_{e}}{U}-1.5\right) D
$$

where

$D$ the internal stack diameter (m),

$\mathrm{W}_{\mathrm{e}}$ effluent velocity $(\mathrm{m} / \mathrm{s})$, and

U crosswind velocity $(\mathrm{m} / \mathrm{s})$. 
Recent work by Snyder (1991) suggests that downwash seldom has consequences due to the fact that conditions are typically associated with small diameters, and the change in stack height due to downwash is only of a few diameters. Snyder states that " serious downwash will occur only for sources with: WD<0.5(60,000)(0.15 $\left.\mathrm{cm}^{2} \mathrm{~s}^{-1}\right) \sim 0.5 \mathrm{~m}^{2} \mathrm{~s}-1$."

\subsubsection{Buoyancy Effects}

For most plumes, the primary contributor to rise is buoyancy which results from density differences between the effluent and the atmosphere. (Briggs, 1984) The initial buoyancy flux for a plume is determined by (Hanna, 1982):

$F_{o}=g(D R H O)(C M S)$

where

$F_{o} \quad$ buoyancy flux $\left(\mathrm{m}^{4} / \mathrm{s}^{3}\right)$

g acceleration due to gravity $\left(9.8 \mathrm{~m} / \mathrm{s}^{2}\right)$,

CMS volume flux at the stack exit $\left(\mathrm{m}^{3} / \mathrm{s}\right)$, and

DRHO density ratio (unitless), defined below.

Plumes are considered dense when the density ratio, $D R H O$, is greater than zero (Meroney, 1982a). DRHO is determined using the following equation:

$D R H O=1-\frac{M W_{a} T_{e}}{M W_{e} T_{a}}$

where

$M W_{e} \quad$ molecular weight of the effluent,

$M W_{a} \quad$ molecular weight of the air (28.9),

$T_{e} \quad$ temperature of effluent (K), and

$T_{a} \quad$ temperature of $\operatorname{air}(\mathrm{K})$.

The Froude number $(F r)$ is used to represent the ratio of inertial forces to buoyancy forces (Snyder, 1972). If DRHO $\leq 0$, the plume is lighter than air and the Froude number is not determined. The plume falls to the ground close to the source when the Froude number is less than 7.7 (Meroney, 1982a). 
$F r=\frac{U}{\sqrt{g * D R H O * D}}$

where

Fr Froude number, unitless,

$U \quad$ wind speed, $\mathrm{m} / \mathrm{s}$, and

$D \quad$ plume exit diameter, $\mathrm{m}$.

For the vertical motion of the plume, the environmental stability parameter, $S$, plays an important role for unstable conditions. The stability parameter is set to unity for all classes except $E, F$ and $G$ where

$S=\frac{g * \frac{\partial T_{a}}{\partial z}}{T_{a}}$

where

$S \quad$ stability parameter, $\mathrm{s}^{-2}$, and

$\frac{\partial T_{e}}{\partial z}=0.02$ for $\mathrm{E}, 0.03$ for $\mathrm{F}$, and $0.04{ }^{\circ} \mathrm{C} / 100 \mathrm{~m}$ for G stability (Hanna, 1982).

For use within the code we will redefine the stability parameter as:

$S P=\sqrt{S}$

Now that many of the initializing parameters have been determined the increase in plume height due to buoyancy can be calculated. For unstable to neutral conditions buoyancy is limited to a distance XSTR from the source using the following formulations (Briggs, 1971):

For $F_{o}>55 \mathrm{~m}^{4} / \mathrm{s}^{3}$

$$
X S T R=120.7 F_{0}^{0.4}(m)
$$

For $F_{o} \leq 55 \mathrm{~m}^{4} / \mathrm{s}^{3}$

$$
X S T R=49.0 F_{0}^{0.625}(m)
$$


Using the above determined distances, the increase in plume height due to buoyancy effects for unstable to neutral conditions where $X<X S T R$ is determined using the following equation (Briggs, 1969):

$$
\Delta h_{B}=1.6 \frac{F_{o}^{1 / 3} X^{2 / 3}}{U}
$$

For distances greater than $X S T R$, the same equation is used, except $\mathrm{X}$ is set to a constant value of XSTR.

For stability classes $\mathrm{E}, \mathrm{F}$ and $\mathrm{G}$ with calm winds (given below) the increase in plume height is determined by the following (Briggs, 1969):

$$
\Delta h_{B}=5.0\left[\frac{F_{o}}{S P^{3}}\right]^{1 / 4}
$$

For stability classes $\mathrm{E}, \mathrm{F}$ and $\mathrm{G}$ with the wind speed greater than the calm wind speed, and for distances greater than XTST=2.07U/SP then buoyancy is less dominating and the increase in plume height is given by the following (Hanna, 1982):

$$
\Delta h_{B}=2.6\left[\frac{F_{o}}{(U) S P^{2}}\right]^{1 / 3}
$$

For distances less than XTST, Equation 15 is applied.

By setting equations 16 and 17 equal and solving for $U$, calm winds are given by the following relationship: $U<0.141^{*}\left(F_{o}{ }^{*} S P\right)^{0.25} \mathrm{~m} / \mathrm{s}$.

\subsubsection{Momentum Effects}

Plume rise may also occur because the initial vertical velocity of the effluent is great enough to elevate the plume. Plume rise due to momentum effects near the source for unstable to neutral weather conditions (Stability Classes A-D) is determined by the following equation (Briggs, 1976):

$$
\Delta h_{M}=\left[\frac{3 \pi}{4 \beta^{2}}\right]^{1 / 3}\left[\frac{D W_{e} M_{0}}{U}\right]^{2 / 3} X^{1 / 3}
$$

where

$\beta \quad=0.4+1.2 U / W_{e}$, (unitless),

$U \quad$ wind speed, $\mathrm{m} / \mathrm{s}$,

$\mathrm{W}_{e}$ effluent velocity, $\mathrm{m} / \mathrm{s}$, 
D diameter of the stack, $m$,

$M_{o}$ measure of relative density of effluent plume to that of air:

$$
M_{0}=\left[\frac{M_{e} T_{a}}{M_{a} T_{e}}\right]^{1 / 2}
$$

$X \quad$ downwind distance, $m$.

For ease in calculation within the program the equation is rewritten as

$$
\Delta h_{M}=\left[B 1 * X * D H M O M^{2}\right]^{1 / 3}
$$

where

$$
\begin{aligned}
& B 1=\frac{0.75 * \pi}{\left(0.4+1.2 U / W_{e}\right)^{2}} \\
& D H M O M=D * \frac{W_{e}}{U} M_{o}
\end{aligned}
$$

with all terms previously defined.

The above equation is applicable for all distances less than XTEST where

$X T E S T=\frac{27.0 D H M O M}{B 1}$

For distances where $\mathrm{X} \geq \mathrm{XTEST}$ the increase in plume height due to momentum effects is given by the following equation (Briggs, 1969):

$$
\Delta h_{M}=3 D H M O M
$$

For stable weather conditions (Stability Classes E, F, and G) the change in plume height due to momentum effects is equal to the minimum of the following two equations (Briggs, 1969):

$$
\begin{aligned}
\Delta h_{M} & =4.0 \sqrt{\frac{D H M O M * U}{2 S P}} \\
\Delta h_{M} & =1.5\left(\frac{D H M O M^{2} U}{4 S P}\right)^{1 / 3}
\end{aligned}
$$




\subsection{Building Wake Effects}

An exact mathematical solution to the plume interaction with air flow does not exist. However, a great deal of useful quantitative information has been obtained using wind-tunnel simulations of flow around model buildings, and a limited number of measurements around full-scale buildings of relatively simple geometry. Semi-empirical models consolidating these simulations and experiments are available for estimating pollutant concentrations around buildings. A summary of the methods available for determining flow patterns and pollutant concentrations near buildings with a simple block-like structure has been prepared by Hanna (1982).

Wind passing over and around buildings creates a complicated dispersion pattern. A recirculation cavity and zones of high turbulence are created on the building roof with a roof cavity region produced downwind of the structure. These regions may trap effluent material and produce high ground- or roof-level concentrations. Models that neglect turbulence effects near structures will usually underestimate pollutant concentrations on building roofs or near buildings. Since air-intake vents may be located on building roofs or near the ground downwind of a release source, an estimation of pollutant concentrations on or near a structure is important in determining expected pollutant levels. Therefore, a methodology was adapted to determine the effect of plume interaction with the air-flow pattern around buildings. This provides a useful tool for determining heights of new stacks so that acceptable pollutant levels near the source and downwind buildings can be assured.

Figure 2 (Wilson, 1979) shows a cross-section of the flow over a building with the wind perpendicular to the face of the building. The recirculation cavity (Zone I) is created due to the separation of the flow from the upwind edge of the roof. The flow recirculates and the turbulence levels are very high. Only if the roof is long enough will the flow reattach to the roof. The boundary of the high turbulence region (Zone II) is not precisely defined. Turbulence generated in the shear layers at the edge of the recirculation cavity result in accelerated diffusion to the roof level of any gases. Zone II is defined such that it also includes Zone I. The roof wake region (Zone III) is depicted in Figure 2 in an exaggerated form. This region's boundary is essentially straight and parallel with the flow. Gases that are released in this region will have some downwash and more rapid spreading than the gases above Zone III. Zone III also includes Zones I and II.

Analytical models have been associated with the regions discussed previously. Building effects are included in the model using the techniques presented by Wilson (1979). The dimensions of recirculation zones, high turbulence zones, and wake cavities associated with the building and any penthouse structure are determined based on building dimensions. If the plume is not over the building or the downwind wake cavity, the height above the ground, $z$, is set equal to zero to give ground-level concentrations. 
Figure 2. Recirculation Zones for Building Wake Effects Calculations.

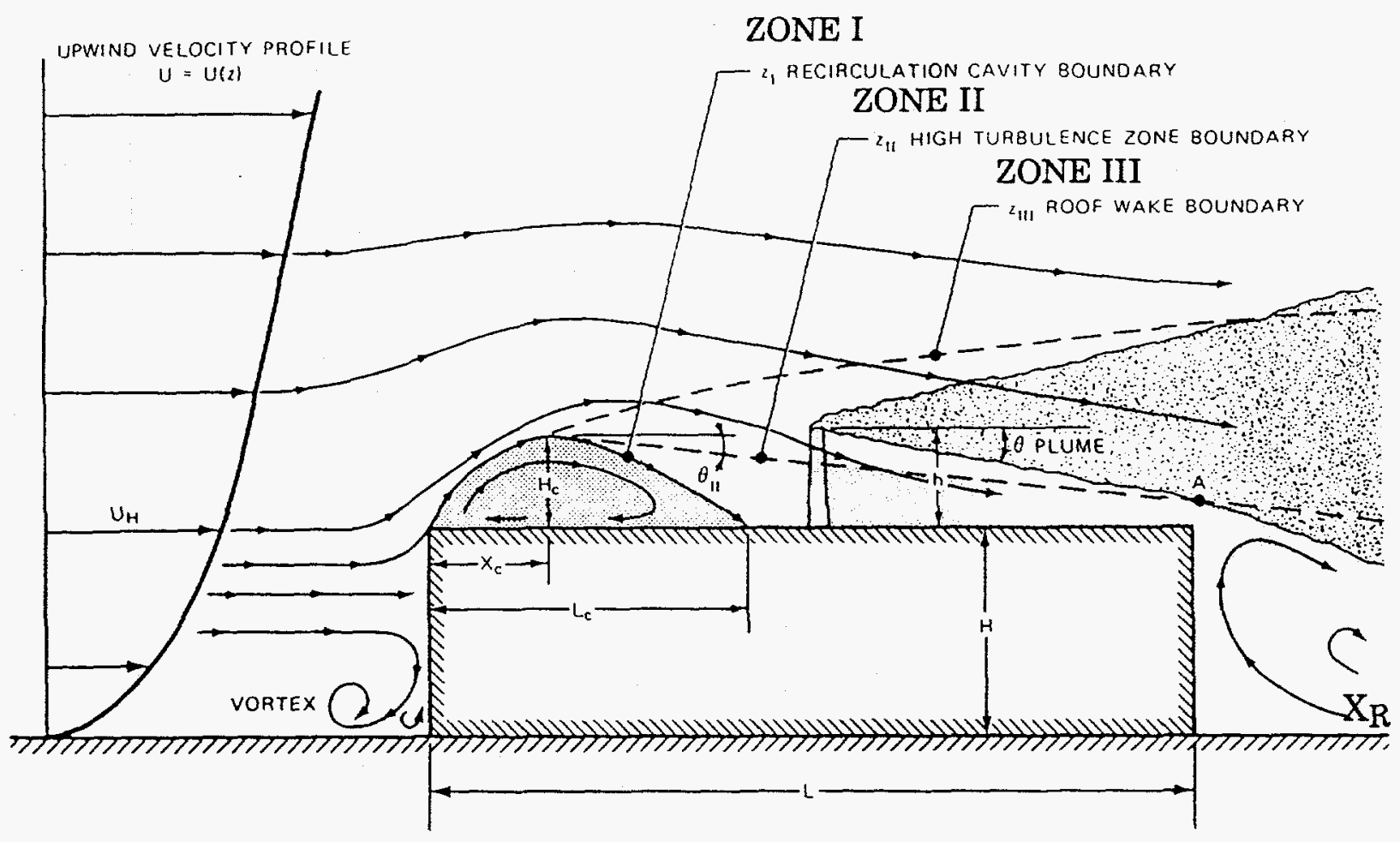

Various fluid modeling experiments have led to the development of models to predict the behavior of wind flow around buildings. The dimensional parameters describing the building of interest in VENTSAR are shown in Figure 3 . These dimensions are consistent with the wind being perpendicular to the building face. When ratios of $\mathrm{L} / \mathrm{H}$ (where $\mathrm{L}$ and $\mathrm{H}$ correspond to the length and height of the building or penthouse) are greater than one, reattachment of streamlines to the roof and sides is expected. This however, may not be the case if $\mathrm{W} / \mathrm{H}$ is very large. The length the recirculation cavity zone (Zone I) extends from the upwind edge of the building is given by the following expression:

$L_{c}=0.9 R$

where

$R \approx\left(B_{\min }\right)^{0.667}\left(B_{\max }\right)^{0.333}$

where $B_{\min }$ is the smaller of $H$ and $W$ and $B_{\max }$ is the larger. The length of the cavity zone should be calculated for both the building and penthouse separately and then summed. All building dimension units are in meters. 
Figure 3. Dimensions of Building and Penthouse used with VENTSAR

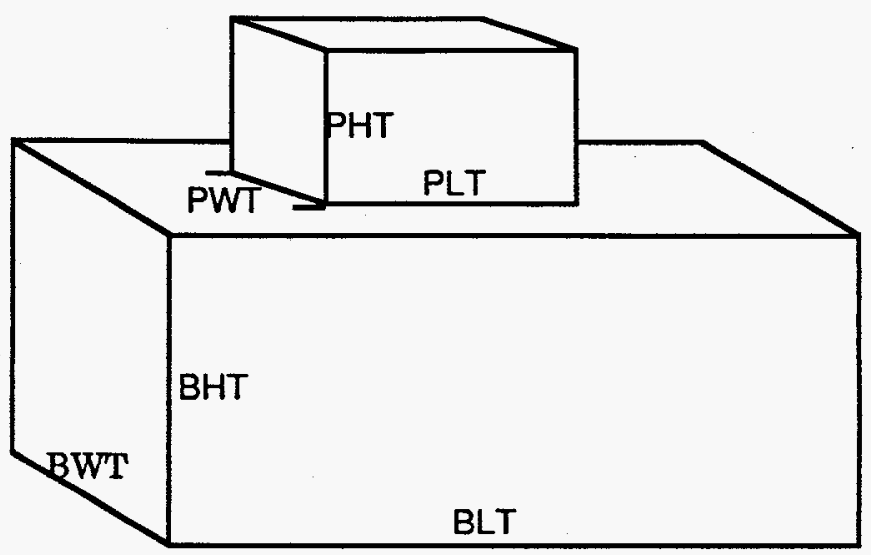

The maximum height of the recirculation zone (Zone I) is

$H_{c} \approx 0.22 R$

and is assumed to occur at a distance of $R / 2$ from the edge of the building. The length of the cavity zone is defined for both the building and the penthouse.

The distance beyond the building where plumes may be caught and mixed to the ground is called the wake cavity. The empirical formula for the length of the wake cavity is (Hanna, 1982):

$$
X_{r}=\frac{A * W}{1+B(W / H)}
$$

where

W the building width,

$H$ the building height, and

$A$ and $B$ are discussed below.

Separate values for $A$ and $B$ are used depending on whether the flow reattaches to the roof and sides of the building. Cases of reattachment occur when $\mathrm{L} / \mathrm{H} \geq 1$. For this case

$A=1.75$

$B=0.25$ 
For cases where the flow does not reattach to the building

$$
\begin{aligned}
& A=-2.0+0.37\left(\frac{L}{H}\right)^{0.33} \\
& B=-0.15+0.305\left(\frac{L}{H}\right)^{0.33}
\end{aligned}
$$

When the recirculation cavity does not reattach to the building roof, calculation of the effective release height is altered. Following Briggs, if the release height $h^{\prime}$ is less than the building height $H$, then the adjusted effective height is given by (Briggs, 1973):

$h_{\text {eff }}=h^{\prime}-1.5 D_{\min }$

where

$h_{\text {eff }}$ the effective plume,

$h^{\prime} \quad$ the release height adjusted by downwash and plume rise, and

$D_{\min }$ the smaller of the width and height of the building.

If the emission height at the building is such that $H<h^{\prime}<H+1.5 D_{\min }$, then the adjusted effective release height is:

$h_{\text {eff }}=2 h^{\prime} \cdot\left(H+1.5 D_{\min }\right)$

If $h^{\prime} \geq H+1.5 D_{\min }$, the plume is out of the wake of the building and no effects from the building are seen, therefore, $h_{\text {eff }}=h^{\prime}$.

When there is a change in elevation on the building roof, three separate flow regimes must be considered. Let $X_{s}$ be the distance from the leading edge of the building to the step change in roof elevation. $R_{u}$ and $R_{s}$ are the scaling lengths given by Equation 28 for the building and penthouse upwind faces, respectively. The following three flow regimes can occur:

(i) $X_{s}<0.5\left(R_{u}+R_{s}\right)$. The leading edge of the building is connected in a straight line to the top of the penthouse to form a recirculation cavity. Roof cavity heights and turbulence zone boundaries are calculated using $R=\left(R_{\mathrm{u}}+\mathrm{R}_{\mathrm{S}}\right)$;

(ii) $0.5\left(R_{u}+R_{s}\right)<X_{s}<2\left(R_{u}+R_{\mathcal{S}}\right)$. The recirculation cavity height $\mathrm{H}_{\mathrm{c}}$ and location $\mathrm{X}_{c}$ on the upwind portion of the roof are calculated using $\mathrm{R}=$ $R_{u}+R_{s}$. The top of this cavity region is joined in a straight line with 
the top of the penthouse to form a high turbulence zone. The cavity height on the penthouse roof and the downwind high turbulence zone boundary are then calculated using $R_{\mathrm{s}}$ as a scale length; or

(iii) $X_{s}>2\left(R_{u}+R_{s}\right)$. The upwind roof and penthouse roof are treated as two separate buildings with scaling lengths $R_{u}$ and $R_{s}$, respectively.

Using the $R$ values determined above for a given point, the height of cavity Zone $\mathrm{I}$ is determined (Wilson, 1979).

For downwind distances less than 0.5R:

$$
Z=0.28 R\left(\frac{X}{R}\right)^{1 / 3}
$$

where

$\mathrm{R}$ determined above based on building dimensions, and

$\mathrm{X}$ downwind distance.

For downwind distance $\mathrm{X}$ where $0.5 \mathrm{R}<\mathrm{X}<\mathrm{L}$ :

$Z=0.27 R-0.1 X$

For use within the code, the value of $\mathrm{Z}$ calculated above is added to the height of the building to determine the relative air concentration. Beyond the building $\mathrm{Z}=0$.

When building wake effects are considered, adjustments must be made to the relative air concentration equation. Some fraction (f) of the effluent plume will be entrained into the wake cavity. For the model used in VENTSAR, this fraction is estimated as the ratio of $\chi / Q$ evaluated at the top of the cavity when it first forms to the value of $\chi / Q$ at the plume centerline. The material trapped within the wake cavity behaves as if it originates from an area source of building dimensions. Meroney (1982b) has shown that a simple expression useful for estimating pollutant concentrations within the cavity is:

$$
\left(\frac{\chi}{Q}\right)_{E}=\frac{f}{H W U_{s}}
$$

Equation 39 assumes that the effluent rapidly mixes in a uniform volume within the cavity. Turbulence within the wake cavity will produce a relatively constant pollutant concentration within this region. Experimental evidence indicates that this assumption will give conservative predictions of ground-level concentrations in most cases. 
For distances beyond the wake cavity, surface $X / Q$ values will contain a component from the elevated plume $(\chi / Q)_{E}$ and from the area source of material trapped within the cavity $(\chi / Q)_{\mathrm{T}}$. Following Hosker $(1984)$, this is expressed as:

$$
\frac{\chi}{Q}=(1-f)\left(\frac{\chi}{Q}\right)_{E}+f\left(\frac{\chi}{Q}\right)_{T}
$$

Meroney (1982b) proposed an empirical expression for $(\chi / Q)_{T}$ as:

$$
\left(\frac{\chi}{Q}\right)_{T}=\left(\frac{\chi}{Q}\right)_{0} \exp \left[-0.5\left(\frac{\chi}{Q}\right)_{0} \pi H W U_{\lrcorner}\left(\frac{h}{H}\right)^{2}\right]
$$

where: $\quad\left(\frac{\chi}{Q}\right)_{0}=\frac{1}{U_{s}\left(\pi \sigma_{y} \sigma_{z}+0.5 H W\right)}$

In Equation 42, $\sigma_{\mathrm{y}}$ and $\sigma_{\mathrm{z}}$ are evaluated using Pasquill and Briggs formulations with $\mathrm{x}$ equal to the distance from the start of the wake cavity. Initial values for $\sigma_{\mathrm{y}}$ and $\sigma_{\mathrm{z}}$ in Equation 42 are taken to be the minimum building cross-sectional dimensions.

\subsection{VERIFICATION OF CALCULATIONS}

Hand calculations were performed to ensure proper application of the previously discussed methodologies. First the building wake module and the plume rise module were tested independently and then together while setting the stability and wind speed to a constant value. The ranking of the $99.5 \%$ values was tested using a simple case with no building or plume rise.

\subsection{Plume Rise Hand Calculations}

Hand calculations were performed to demonstrate the plume rise module was performing correctly. Table 4 shows the input parameters that were used for the computer run to verify the plume rise module. Variables were chosen at random within the ranges of validity.

Table 5 shows the comparison of hand calculations to computer output for various downwind distances. Differences are slight and likely attributable to rounding errors. See Appendix A, Section 1 for the actual hand calculations. 
Table 4. Input parameters for Plume Rise Verification.

\begin{tabular}{|l|l|}
\hline Parameter & Input \\
\hline Area or Release Location & $\mathrm{A}$ \\
English or Metric & $\mathrm{M}$ (metric) \\
Building Height & $0.0 \mathrm{~m}$ \\
Building Width & $0.0 \mathrm{~m}$ \\
Building Length & $0.0 \mathrm{~m}$ \\
Penthouse Height & $0.0 \mathrm{~m}$ \\
Penthouse Width & $0.0 \mathrm{~m}$ \\
Penthouse Length & $0.0 \mathrm{~m}$ \\
Penthouse Distance & $0.0 \mathrm{~m}$ \\
Minimum Distance of Interest & $10 \mathrm{~m}$ \\
Maximum Distance of Interest & $1010 \mathrm{~m}$ \\
Compass Sector of Building Location & 3 \\
Distance of Vent from Roof Edge & -10.0 \\
Vent Height & $20.0 \mathrm{~m}$ \\
Radioactive Calculation? & $\mathrm{No}$ \\
Release Rate & 0 \\
Mole Fraction of Pollutant & $1.8 \mathrm{E}-03$ \\
Vent Gas Flow Rate & $50 \mathrm{~m} / \mathrm{s}$ \\
Averaging Option & $\mathrm{No}$ \\
Wind Speed & $6 \mathrm{~m} / \mathrm{s}$ \\
Stability Class & $4(\mathrm{D})$ \\
Vent Diameter & $1.0 \mathrm{~m}$ \\
Vent Gas Molecular Weight & 78.12 \\
Vent Gas Air Temperature & $40 \mathrm{C}$ \\
Air Temperature & $20 \mathrm{C}$ \\
Four Vents? & $\mathrm{no}$ \\
\hline
\end{tabular}

Table 5. Hand Calculations for Plume Rise Verification

\begin{tabular}{|c|c|c|c|}
\hline $\begin{array}{l}\text { Downwind } \\
\text { Distance }(\mathrm{m})\end{array}$ & $\begin{array}{l}\text { Relative Air } \\
\text { Concentration }\left(\mathrm{s} / \mathrm{m}^{3}\right)\end{array}$ & $\begin{array}{l}\text { Relative Air } \\
\text { VENTSAR }\end{array}$ & $\begin{array}{l}\text { Percent } \\
\text { Voncentration }\left(\mathrm{s} / \mathrm{m}^{3}\right)\end{array}$ \\
Difference \\
\hline 10 & $0.00 \mathrm{E}+00$ & $0.00 \mathrm{E}+00$ & $0.0 \%$ \\
200 & $8.16 \mathrm{E}-17$ & $8.18 \mathrm{E}-17$ & $-0.2 \%$ \\
1000 & $4.40 \mathrm{E}-07$ & $4.40 \mathrm{E}-07$ & $0.0 \%$ \\
\hline
\end{tabular}

\subsection{Building Wake Effects}

Table 6 shows the input parameters that were used to verify the building wake effects module. Figure 4 shows a side view of the building and the places at which hand calculations were performed to verify the concentrations. These locations were selected to ensure all zones were considered. 
Figure 4. Concentration locations for Building Wake Effects Verification

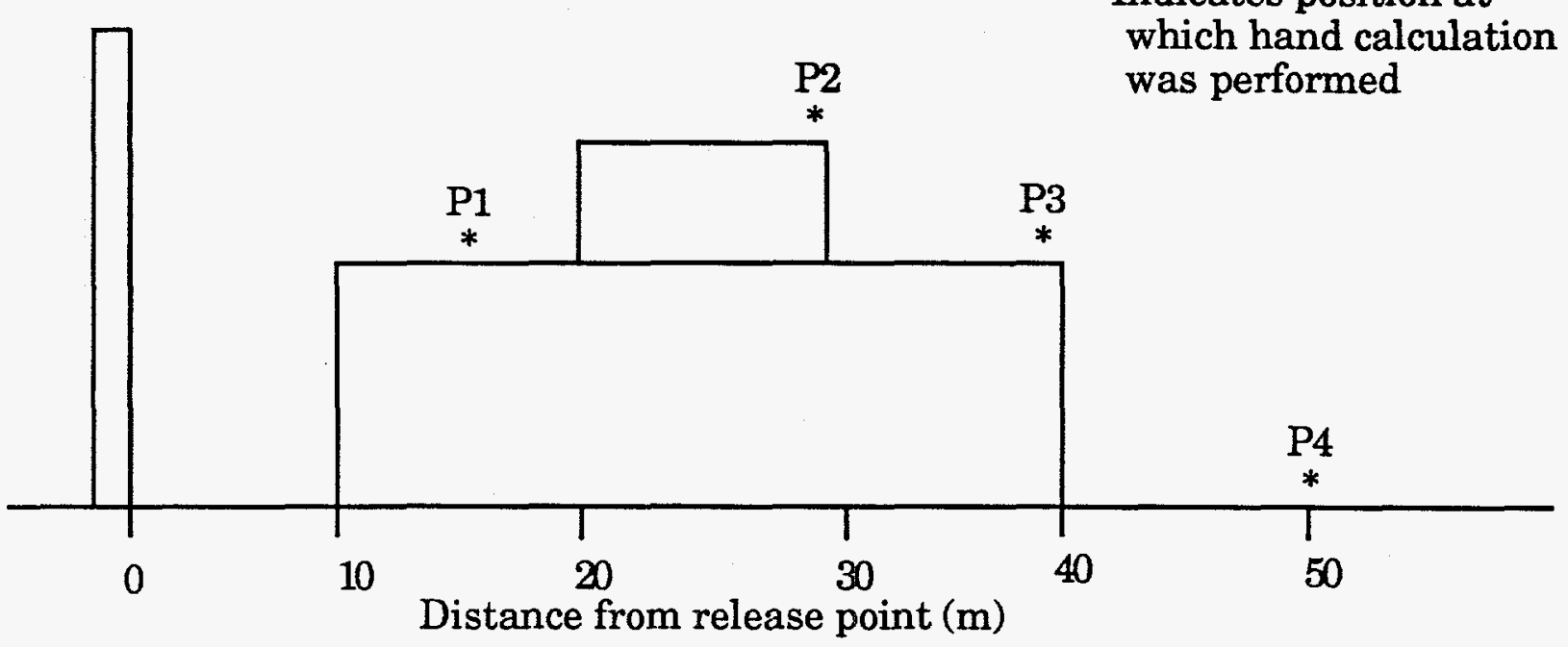

Table 6. Input parameters for Building Wake Effects Verification

\begin{tabular}{|l|l|}
\hline Parameter & Input \\
\hline Area or Release Location & $\mathrm{K}$ \\
English or Metric & $\mathrm{M}$ (metric) \\
Building Height & $10.0 \mathrm{~m}$ \\
Building Width & $20.0 \mathrm{~m}$ \\
Building Length & $30.0 \mathrm{~m}$ \\
Penthouse Height & $5.0 \mathrm{~m}$ \\
Penthouse Width & $10.0 \mathrm{~m}$ \\
Penthouse Length & $10.0 \mathrm{~m}$ \\
Penthouse Distance & $10.0 \mathrm{~m}$ \\
Minimum Distance of Interest & $10 \mathrm{~m}$ \\
Maximum Distance of Interest & $1010 \mathrm{~m}$ \\
Compass Sector of Building Location & 3 \\
Distance of Vent from Roof Edge & -10.0 \\
Vent Height & $20.0 \mathrm{~m}$ \\
Radioactive Calculation? & Yes \\
Release Rate & $1 \mathrm{Ci} / \mathrm{min}$ \\
Mole Fraction of Pollutant & 0 \\
Vent Gas Flow Rate & 0 \\
Averaging Option & $\mathrm{No}$ \\
Wind Speed & $6 \mathrm{~m} / \mathrm{s}$ \\
Stability Class & $4(\mathrm{D})$ \\
Vent Diameter & $0.1 \mathrm{~m}$ \\
Vent Gas Molecular Weight & 78.12 \\
Vent Gas Temperature & 0 \\
Ambient Air Temperature & 0 \\
Four Vents? & $\mathrm{no}$ \\
Vent Height & $20 \mathrm{~m}$ \\
\hline
\end{tabular}


Table 7 shows the results of the comparison. The differences are negligible. See Appendix A, Section 2 for the hand calculations.

Table 7. Hand Calculations for Building Wake Effects Verification

\begin{tabular}{|c|c|c|c|}
\hline $\begin{array}{l}\text { Downwind } \\
\text { Distance (m) } \\
\text { (Position) }\end{array}$ & $\begin{array}{l}\text { Relative Air } \\
\text { Concentration }\left(\mathrm{s} / \mathrm{m}^{3}\right) \\
\text { VENTSAR }\end{array}$ & $\begin{array}{l}\text { Relative Air } \\
\text { Concentration }\left(\mathrm{s} / \mathrm{m}^{3}\right) \\
\text { Hand Calculations }\end{array}$ & $\begin{array}{c}\text { Percent } \\
\text { Difference }\end{array}$ \\
\hline $\begin{array}{ll}15 & (\mathrm{P} 1) \\
30(\mathrm{P} 2) \\
40(\mathrm{P} 3) \\
50(\mathrm{P} 4)\end{array}$ & $\begin{array}{l}1.13 \mathrm{E}-14 \\
4.69 \mathrm{E}-05 \\
3.16 \mathrm{E}-19 \\
8.42 \mathrm{E}-14 \\
\end{array}$ & $\begin{array}{l}1.13 \mathrm{E}-14 \\
4.69 \mathrm{E}-05 \\
3.16 \mathrm{E}-19 \\
8.42 \mathrm{E}-14\end{array}$ & $\begin{array}{l}0.0 \% \\
0.0 \% \\
0.0 \% \\
0.0 \%\end{array}$ \\
\hline
\end{tabular}

\subsection{Plume Rise and Building Options Combined}

A case with both a simple building and plume rise was analyzed. The input parameters for this comparison are shown in Table 8. The results of the hand calculations compared with the actual code output are shown in Table 9. The differences were $1 \%$ or less for all of the positions selected.

Table 8. Input parameters for Building Wake Effects and PR Verification

\begin{tabular}{|l|l|}
\hline Parameter & Input \\
\hline Area or Release Location & $\mathrm{A}$ \\
English or Metric & $\mathrm{M}$ (metric) \\
Building Height & $10.0 \mathrm{~m}$ \\
Building Width & $20.0 \mathrm{~m}$ \\
Building Length & $30.0 \mathrm{~m}$ \\
Penthouse Height & $0.0 \mathrm{~m}$ \\
Penthouse Width & $0.0 \mathrm{~m}$ \\
Penthouse Length & $0.0 \mathrm{~m}$ \\
Penthouse Distance & $0.0 \mathrm{~m}$ \\
Minimum Distance of Interest & $10 \mathrm{~m}$ \\
Maximum Distance of Interest & $1010 \mathrm{~m}$ \\
Compass Sector of Building Location & 3 \\
Distance of Vent from Roof Edge & -10.0 \\
Vent Height & $0.0 \mathrm{~m}$ \\
Radioactive Calculation? & Yes \\
Release Rate & $1 \mathrm{Ci} / \mathrm{min}$ \\
Mole Fraction of Pollutant & 0 \\
Vent Gas Flow Rate & 0 \\
Averaging Option & $\mathrm{No}$ \\
Wind Speed & $4 \mathrm{~m} / \mathrm{s}$ \\
Stability Class & $3(\mathrm{C})$ \\
Vent Diameter & $1 \mathrm{~m}$ \\
Vent Gas Molecular Weight & 78.12 \\
Vent Gas Temperature & $40 \mathrm{C}$ \\
Ambient Air Temperature & $20 \mathrm{C}$ \\
Four Vents & $\mathrm{no}$ \\
\hline
\end{tabular}


Table 9. Hand Calculations for Building Wake Effects and PR Verification

\begin{tabular}{|c|c|c|c|}
\hline $\begin{array}{l}\text { Downwind } \\
\text { Distance }(\mathrm{m})\end{array}$ & $\begin{array}{l}\text { Relative Air } \\
\text { Concentration }\left(\mathrm{s} / \mathrm{m}^{3}\right) \\
\text { VENTSAR }\end{array}$ & $\begin{array}{l}\text { Relative Air } \\
\text { Concentration }\left(\mathrm{s} / \mathrm{m}^{3}\right) \\
\text { Hand Calculations }\end{array}$ & $\begin{array}{c}\text { Percent } \\
\text { Difference }\end{array}$ \\
\hline 30 & $7.85 \mathrm{E}-73$ & $7.90 \mathrm{E}-73$ & $-0.6 \%$ \\
45 & $9.60 \mathrm{E}-69$ & $9.70 \mathrm{E}-69$ & $-1.0 \%$ \\
100 & $9.82 \mathrm{E}-23$ & $9.85 \mathrm{E}-23$ & $-0.3 \%$ \\
500 & $1.89 \mathrm{E}-07$ & $1.89 \mathrm{E}-07$ & $0.0 \%$ \\
\hline
\end{tabular}

\subsection{Averaging Option Hand Calculations}

Verification of the averaging option within VENTSAR was accomplished by setting up a Microsoft EXCEL Spreadsheet that would calculate and sort the 42 separate $\mathrm{X} / \mathrm{Qs}$ for a particular sector. Table 10 shows the input parameters for the calculation. Copies of the spreadsheets used to calculate the relative air concentrations are shown in Appendix A, Section 4.

Table 10. Input parameters for Averaging Option

\begin{tabular}{|l|l|}
\hline Parameter & Input \\
\hline Area & $\mathrm{K}$ \\
English or Metric & $\mathrm{M}$ (metric) \\
Building Height & $0.0 \mathrm{~m}$ \\
Building Width & $0.0 \mathrm{~m}$ \\
Building Length & $0.0 \mathrm{~m}$ \\
Penthouse Height & $0.0 \mathrm{~m}$ \\
Penthouse Width & $0.0 \mathrm{~m}$ \\
Penthouse Length & $0.0 \mathrm{~m}$ \\
Penthouse Distance & $0.0 \mathrm{~m}$ \\
Minimum Distance of Interest & $10 \mathrm{~m}$ \\
Maximum Distance of Interest & $1010 \mathrm{~m}$ \\
Compass Sector of Building Location & 1 \\
Distance of Vent from Roof Edge & -10.0 \\
Vent Height & $20.0 \mathrm{~m}$ \\
Radioactive Calculation? & Yes \\
Release Rate & $100 \mathrm{Ci} / \mathrm{min}$ \\
Mole Fraction of Pollutant & 0 \\
Averaging Option & Yes \\
Percentage & $0.5 \%$ \\
Plume Rise & No \\
Vent Diameter & $0.1 \mathrm{~m}$ \\
Vent Gas Molecular Weight & NA \\
Vent Gas Air Temperature & NA \\
Air Temperature & NA \\
Vent Gas Flow Rate & NA \\
Four Vents? & no \\
\hline
\end{tabular}


Table 11 shows the results of the hand calculation when compared to the VENTSAR output. No differences were found. Using the same EXCEL Spreadsheet the Annual Average X/Q values were also verified and the comparison of with actual code output is shown in Table 12.

Table 11. Hand Calculations for Averaging Option Verification

\begin{tabular}{|c|c|c|c|}
\hline $\begin{array}{l}\text { Downwind } \\
\text { Distance }(\mathrm{m})\end{array}$ & $\begin{array}{l}\text { Relative Air } \\
\text { Concentration }\left(\mathrm{s} / \mathrm{m}^{3}\right) \\
\text { VENTSAR }\end{array}$ & $\begin{array}{l}\text { Relative Air } \\
\text { Concentration }\left(\mathrm{s} / \mathrm{m}^{3}\right) \\
\text { Hand Calculations }\end{array}$ & $\begin{array}{l}\text { Percent } \\
\text { Difference }\end{array}$ \\
\hline $\begin{array}{r}200 \\
5000 \\
10050\end{array}$ & $\begin{array}{l}1.74 \mathrm{E}-04 \\
8.58 \mathrm{E}-07 \\
3.45 \mathrm{E}-07\end{array}$ & $\begin{array}{l}1.74 \mathrm{E}-04 \\
8.58 \mathrm{E}-07 \\
3.45 \mathrm{E}-07\end{array}$ & $\begin{array}{l}0.0 \% \\
0.0 \% \\
0.0 \%\end{array}$ \\
\hline
\end{tabular}

Table 12. Hand Calculations for Annual Average Concentration

\begin{tabular}{|c|c|c|c|}
\hline $\begin{array}{l}\text { Downwind } \\
\text { Distance (m) }\end{array}$ & $\begin{array}{l}\text { Annual Average } \\
\text { Relative Air } \\
\text { Concentration (s/m } \\
\text { VENTSAR }\end{array}$ & $\begin{array}{l}\text { Annual Average } \\
\text { Relative Air } \\
\left.\text { Concentration (s/m }{ }^{3}\right) \\
\text { Hand Calculations }\end{array}$ & $\begin{array}{l}\text { Percent } \\
\text { Difference }\end{array}$ \\
\hline 200 & $5.27 \mathrm{E}-06$ & $5.27 \mathrm{E}-06$ & $0.0 \%$ \\
5000 & $3.29 \mathrm{E}-08$ & $3.29 \mathrm{E}-08$ & $0.0 \%$ \\
10050 & $1.45 \mathrm{E}-08$ & $1.45 \mathrm{E}-08$ & $0.0 \%$ \\
\hline
\end{tabular}

\subsection{CONCLUSIONS}

VENTSAR has been verified and is operating as expected. All equations were verified to their original source and hand calculations were performed to ensure proper application of the methodologies. Test cases are performed semi-annually to ensure that VENTSAR continually operates as expected. 


\subsection{REFERENCES}

Briggs, G.A., 1969: Plume Rise, Air Resources Atmospheric Turbulence and Diffusion Laboratory, TID-25075, USAEC, Division of Technical Information.

Briggs, G.A., 1973: "Diffusion Estimation for Small Emissions", in Environmental Research Laboratory, Air Resources Atmospheric Turbulence and Diffusion Laboratory, Annual Report, ATDL-106, USDOC-NOAA.

Briggs, G.A., 1976: "Plume Rise Predictions", Lectures on Air Pollution and Environmental Impact Analyses, American Meteorological Society, Boston, Mass.

Briggs, G.A., 1984: "Plume Rise and Buoyancy Effects", Atmospheric Science and Power Production, DOE/TIC-27601, p 327.

Garrett, A. J., 1982: and D.D. Hoel, Preparation of Meteorological Data for Dose Calculations in 1982 SRP Reactor Safety Analysis Report (SAR), USDOE Report DPST-82-512, Savannah River Laboratory, Aiken, SC.

Hanna, S. R., 1982: and G. A. Briggs, and R. P. Hosker, Jr., Handbook on Atmospheric Diffusion. DOE/TIC-11223 (DE82002045) Technical Information Center, USDOE.

Hosker, R.P., 1984: "Flow and Diffusion Near Obstacles", Atmospheric Science and Power Production, DOE/TIC-27601, p 241.

Meroney, R.N., 1982a: "Wind-Tunnel Experiments on Dense Gas Dispersion. Journal of Hazardous Materials", Journal of Hazardous Materials 6, $\mathrm{p}$ 85.

Meroney, R.N., 1982b: Engineering Meteorology, E.J. Plate, Editor, Elsevier Scientific Publishing Company, New York.

Parker, M.J., 1992: The 1987-1991 Savannah River Site Meteorological Data Base(U), USDOE Report WSRC-RP-92-598, Westinghouse Savannah River Company, Aiken, SC.

Pasquill, F., 1961: "The Estimation of the Dispersion of Windborne Material", Meteorological Magazine 90, p 33.

Pasquill, F., 1976: Atmospheric Dispersion Parameters in Gaussian Plume Modeling: Part II. Possible Requirements for Change in the Turner Workbook Values, EPA Report EPA-600/4-76306, US Environmental Protection Agency. 
Snyder, W.H. 1972: "Similarity Criteria for the Application of Fluid Models to the Study of Air Pollution Meteorology", Boundary-Layer Meteorology 3, D. Reidel Publishing Company, Dordrecht-Holland, $\mathrm{p}$ 113.

Snyder, W.H. 1991: "Fluid Modeling Simulation of Stack-Tip Downwash for Neutrally Buoyant Plumes", Atmospheric Environment, Volume 25A, No $12, \mathrm{p} 2937$.

Weber, A.H., 1993: Comparison of Savannah River Site's Meteorological Databases(U), USDOE Report WSRC-RP-93-269, Westinghouse Savannah River Company, Aiken, SC.

Wilson, D.J., 1979: "Flow Patterns Over Flat-Roofed Buildings and Application to Exhaust Stack Design", ASHRAE Transactions 85, Part $2, \mathrm{p} 284$. 
APPENDIX A. HAND CALCULATIONS 


\section{APPENDIX A. HAND CALCULATIONS}

Independent calculations were performed to determine if VENTSAR was correctly applying the methodologies previously discussed. Calculations were done using an EXCEL Spreadsheet and by hand when necessary. VENTSAR input may be in English or Metric units. Regardless of which the user chooses, the calculations are done in metric after the necessary conversions are done. All of the conversions were verified and the problems that follow use metric units.

\subsection{Plume Rise Options}

The constants used in the plume rise equations were calculated using a Microsoft EXCEL spreadsheet. A copy of this spreadsheet is shown as Figure A1. For a downwind distance of $10 \mathrm{~m}$ the following calculations were performed using the parameters shown in Table 4.

Buoyancy Effects

From the Spreadsheet in Figure A1:

$\mathrm{DRHO}=0.031$

DELI $=-0.065$

$\mathrm{F}_{0}=29.91 \mathrm{~m}^{4} / \mathrm{s}^{3}$

$\mathrm{XSTR}=409.80 \mathrm{~m}$

Since the weather conditions are neutral (D stability) the value of the stability parameter, $\mathrm{S}$, is one. Increase in release height due to buoyancy is:

$$
\Delta h_{B}=1.6 \frac{F_{0}^{1 / 3} X^{2 / 3}}{U}=1.6 \frac{29.91^{1 / 3} 10^{2 / 3}}{6}=3.84 \mathrm{~m}
$$

Momentum Effects

From the EXCEL Spreadsheet shown in Figure A1:

$\mathrm{B} 1=8.95$

$\mathrm{We}=63.7 \mathrm{~m} / \mathrm{s}$

$\mathrm{Mo}=0.939$

DHMOM $=10.28 \mathrm{~m}$ 
Figure A1. Constants for Plume Rise Calculation

\begin{tabular}{|c|c|c|c|c|}
\hline & & & & \\
\hline & & \multicolumn{2}{|c|}{ VENTSAR } & \\
\hline & & & & \\
\hline & & \multicolumn{3}{|c|}{ Plume Rise Verification } \\
\hline & & & & \\
\hline & & & & \\
\hline & & & & \\
\hline Release Location & $A$ & porits & & \\
\hline$(A, C, D, F, H, K, P$, or $O$ for other $)$ & 0 & & & \\
\hline Grid Coordinates Easting & & $\mathrm{ft}$ & & \\
\hline Northing & & $\mathrm{ft}$ & & \\
\hline Building Dimensions & & & & \\
\hline Building Height & 0 & $\mathrm{~m}$ & bmin & 0 \\
\hline Building Width & $\overline{0}$ & m & bmax & 0 \\
\hline Building Length & $\overline{0}$ & $\mathrm{~m}$ & ru & 0 \\
\hline Penthouse Height & $\overline{0}$ & $\sqrt{m}$ & pmin & 0 \\
\hline Penthouse Width & 0 & $m$ & pmax & 0 \\
\hline Penthouse Length & 0 & $\mathrm{~m}$ & rs & 0 \\
\hline Distance to Penthouse on Rooftop & 0 & $m$ & $r$ & 0 \\
\hline (Negative indicates on roof) & & & & \\
\hline Minimum Distance of Interest & 10 & $\mathrm{~m}$ & delx & 5 \\
\hline Maximum Distance of Interest & 1010 & $m$ & & \\
\hline Number of Increments & 200 & & We- & 63.662031 \\
\hline Compass Sector of Building & 1 & & $67:=$ & 8.94976047 \\
\hline$(1-N, 2-N N E, \ldots)$ & & & Otirinen & 102814263 \\
\hline Distance of Vent from Roof Edge & 10 & $m$ & M10: & 6.93896252 \\
\hline (negative is upwind) & & & $1=$ & "I: \\
\hline Vent Height & 20 & $\mathrm{~m}$ & 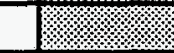 & \\
\hline Radioactive Calculations(y or $n$ ) & $n$ & & 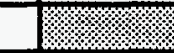 & $l_{x \rightarrow \infty}$ \\
\hline If yes Release Rate & & $\mathrm{Ci} / \mathrm{yr}$ & 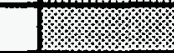 & 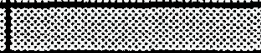 \\
\hline If No Mole Fraction of Vent Gas & $1.80 \mathrm{E}-03$ & & $\because \geq$ & \\
\hline $\begin{array}{l}\text { Vent Gas Flow Rate } \\
\end{array}$ & 50 & $\mathrm{~m} 3 / \mathrm{s}$ & খ & \\
\hline Averaging Option ( $\mathrm{Y}$ or $\mathrm{N})$ & $\mathrm{N}$ & & Ea & 293. \\
\hline If Yes Specify Probability Level & & & Ke: & $8 \longdiv { 3 }$ \\
\hline If No Wind speed at Vent Height & 6 & $\mathrm{~m}$ & Esi: & 6.8 \\
\hline Stability Class ( $1-7$ to $A-G)$ & D & & dietive & 0.0650052 \\
\hline Plume Rise $(\mathrm{Y}$ or $\mathrm{N})$ & & & 19wa & $28.966: 1: 1: 0$ \\
\hline Vent Diameter & 1 & $\mathrm{~m}$ & 2alea & 0.7853975 \\
\hline Gas Molecular Weight & 78.12 & & We: & 63.6620311 \\
\hline Vent Gas Temperature & 40 & C & me & 290488488 \\
\hline Ambient Air Temperature & 20 & C & dito & 603051874 \\
\hline Use of Four Vent Heights $(Y$ or $N)$ & $\mathrm{N}$ & & ER: & NA \\
\hline Enter Minimum Height & 20 & $\mathrm{~m}$ & 10: & 29.9083652 \\
\hline Increment Height & 0 & Im & XSTR & 409794855 \\
\hline
\end{tabular}


Using the above parameters, XTEST can be calculated as follows:

$$
X T E S T=\frac{27.0 * D H M O M}{B 1}=\frac{27.0 * 10.28}{8.95}=31.01 \mathrm{~m}
$$

Since $\mathrm{X}$ is less than XTEST

$$
\Delta h_{m}=\left(B 1 * X * D H M O M^{2}\right)^{1 / 3}=\left(8.95 * 10 * 10.28^{2}\right)^{1 / 3}=21.15 m
$$

There is no downwash since $\mathrm{W} / \mathrm{U}>1.5$.

The effective change in plume height is

$$
\begin{aligned}
& h(x)=h_{s}-\Delta h_{D}+\Delta h_{B}(x)+\Delta h_{M}(x) \\
& h(x)=20.0-0.00+3.84+21.15=44.99 m
\end{aligned}
$$

This number is in agreement with the effective plume height shown on the output.

From another EXCEL Spreadsheet the pollutant concentration is calculated to be $6.6 \mathrm{E}-174 \mathrm{~s} / \mathrm{m}^{3}$ which is assumed to be $0.00 \mathrm{E}+00 \mathrm{~s} / \mathrm{m}^{3}$.

The following hand calculation is for a downwind distance of $\mathrm{X}=200 \mathrm{~m}$.

Using the same constants as above and since $\mathrm{X}<\mathrm{XSTR}$

$$
\Delta h_{B}=1.6 \frac{F_{0}^{1 / 3} X^{2 / 3}}{U}=1.6 \frac{29.91^{1 / 3} 200^{2 / 3}}{6}=28.31 \mathrm{~m}
$$

For momentum effects, $\mathrm{X}>\mathrm{XTEST}$ yielding

$$
\begin{aligned}
\Delta h_{m} & =3 * D H M O M=3 * 10.28=30.84 m \\
h(x) & =20.0-0.00+28.31+30.84=79.15 m
\end{aligned}
$$

From an EXCEL Spreadsheet the pollutant concentration is $8.18 \mathrm{E}-17 \mathrm{~s} / \mathrm{m}^{3}$. 
The following hand calculation is for a downwind distance of $X=1000 \mathrm{~m}$.

Since $\mathrm{X}>\mathrm{XSTR}$ the same equation is used as above except $\mathrm{X}$ is replaced with the value of XSTR.

$$
\begin{aligned}
\Delta h_{B} & =1.6 \frac{F_{o}{ }^{1 / 3} X S T R^{2 / 3}}{U} \\
\Delta h_{B} & =1.6 \frac{29.91^{1 / 3} 409.79^{2 / 3}}{6}=45.67 \mathrm{~m}
\end{aligned}
$$

For momentum effects, $\mathrm{X}>\mathrm{XTEST}$ yielding

$$
\begin{aligned}
& \Delta h_{m}=3 * \text { DHMOM }=3 * 10.28=30.84 m \\
& h(x)=20.0-0.00+45.67+30.84=96.51 m
\end{aligned}
$$

From an EXCEL Spreadsheet the pollutant concentration is $4.40 \mathrm{E}-07 \mathrm{~s} / \mathrm{m}^{3}$.

\subsection{Building Wake Effects}

The building wake effects will be verified using the input that was specified in Table 6 of the text.

For a downwind distance of $15 \mathrm{~m}$, the length which the recirculation cavity zone extends from the upwind edge of the building is determined using the following expression:

$\mathrm{L}_{\mathrm{c}} \approx 0.9 \mathrm{R}$

where

$R \approx\left(B_{\min }\right)^{0.667}\left(B_{\max }\right)^{0.333}$

where $B_{\min }$ is the smaller of $H$ and $W$ and $B_{\max }$ is the larger.

For the building

$R_{u} \approx(10)^{0.667}(20)^{0.333}$

$\mathrm{R}_{\mathrm{u}} \approx 12.6 \mathrm{~m}$

The total is $18.9 \mathrm{~m}$.
For the penthouse

$$
\begin{aligned}
& \mathrm{R}_{\mathrm{S}} \approx(5)^{0.667}(10)^{0.333} \\
& \mathrm{R}_{\mathrm{S}} \approx 6.3 \mathrm{~m}
\end{aligned}
$$


Next a series of tests must be performed as shown in Section 3.3 to determine the correct characteristic length to use for the remainder of the equations. The variable $X_{s}$ is equal to the length from the release point to the nearest edge of the building $(10 \mathrm{~m})$.

The conditions for this problem fell into the second set of criteria which are shown as follows.

(ii) $0.5\left(\mathrm{R}_{\mathrm{u}}+\mathrm{R}_{\mathrm{s}}\right)<\mathrm{X}_{\mathrm{s}}<2\left(\mathrm{R}_{\mathrm{u}}+\mathrm{R}_{\mathrm{s}}\right)$. $0.5(18.9)<10<2(18.9)$ is true therefore the recirculation cavity height $\mathrm{H}_{\mathfrak{c}}$ and location $\mathrm{X}_{\mathfrak{c}}$ on the upwind portion of the roof are calculated using $R=R_{u}+R_{s}$. The top of this cavity region is joined in a straight line with the top of the penthouse to form a high turbulence zone. The cavity height on the Penthouse roof and the downwind high turbulence zone boundary are then calculated using $R_{\mathrm{s}}$ as a scale length.

Since the position that has been chosen is on the upwind portion of the penthouse, $R_{\text {total }}$ will be used to determine the cavity height and length as follows:

$\mathrm{H}_{\mathrm{c}}=0.22 \mathrm{R}_{\text {total }}$

$\mathrm{H}_{\mathrm{c}}=0.22 * 18.86 \mathrm{~m}$

$\mathrm{H}_{\mathrm{c}}=4.15 \mathrm{~m}$

$$
\mathrm{X}_{\mathrm{c}}=0.5 \mathrm{R}_{\text {total }}
$$$$
\mathrm{X}_{\mathrm{c}}=0.5 * 18.86 \mathrm{~m}
$$

$X_{c}=9.43 \mathrm{~m}$

The empirical formula for the length of the wake cavity is:

$\mathrm{X}_{\mathrm{r}}=\frac{\mathrm{A}^{*} \mathrm{~W}}{1+\mathrm{B}(\mathrm{W} / \mathrm{H})}$

Two separate combinations of values for $\mathrm{A}$ and $\mathrm{B}$ are used depending on whether the flow reattaches to the roof and sides of the building. Cases of reattachment occur when the roof cavity length $\left(L_{c}\right)$ is less than the length of the building.

Test to see if $0.9 R_{\text {total }}<X_{c}$

$0.9 * 18.86<20$ is true.

For this case $\mathrm{A}=1.75$ and $\mathrm{B}=0.25$.

Using

$\mathrm{X}_{\mathrm{r}}=\frac{1.75 * 20 \mathrm{~m}}{1+0.25(20 / 10)}$ 
$\mathrm{X}_{\mathrm{r}}=23.33 \mathrm{~m}$

Since $\mathrm{X}_{\mathrm{s}}<0.5 \mathrm{R}$

$\mathrm{Z}_{\mathrm{eff}}=0.28 * \mathrm{R} *\left[\frac{\mathrm{X}}{\mathrm{R}}\right]^{0.333}$

$\mathrm{Z}_{\mathrm{eff}}=0.28 * 18.86 \mathrm{~m} *\left[\frac{5}{18.86}\right]^{0.333}$

$\mathrm{Z}_{\mathrm{eff}}=3.39 \mathrm{~m}$

$\mathrm{Z}_{\mathrm{tot}}=\mathrm{Z}_{\mathrm{eff}}+\mathrm{BHT}=3.39 \mathrm{~m}+10 \mathrm{~m}=13.39 \mathrm{~m}$

Now to determine the relative air concentration

$\frac{\chi}{Q}=\frac{1}{2 \pi \sigma_{y} \sigma_{z} U_{S}}\left[e^{-\left(\frac{\left(z-h_{s}\right)^{2}}{2 \sigma_{z}^{2}}\right)}+e^{-\left(\frac{\left(z+h_{c}\right)^{2}}{2 \sigma_{z}^{2}}\right)}\right]$

For D stability $15 \mathrm{~m}$ downwind of release location

$$
\begin{array}{ll}
\sigma_{\mathrm{y}}=\frac{\sigma_{\theta} \mathrm{x}}{1+0.031(\mathrm{x})^{0.46}} & \sigma_{\mathrm{z}}=0.06 \mathrm{x}(1+0.0015 \mathrm{x})^{-0.5} \\
\sigma_{\mathrm{y}}=\frac{0.218 * 15 \mathrm{~m}}{1+0.031(15)^{0.46}} & \sigma_{\mathrm{z}}=0.06^{*} 15 \mathrm{~m}(1+0.0015 * 15)^{-0.5} \\
\sigma_{\mathrm{y}}=2.954 \mathrm{~m} & \sigma_{\mathrm{z}}=0.890 \mathrm{~m} \\
\frac{\chi}{\mathrm{Q}}=\frac{\mathrm{e}^{-0.5((13.4-20) / 0.89)^{2}}+\mathrm{e}^{-0.5((13.4+20) / 0.89)^{2}}}{2^{*} 3.14 * 2.954 \mathrm{~m}^{*} 0.890 \mathrm{~m}^{*} 6 \mathrm{~m} / \mathrm{s}}=1.13 \mathrm{E}-14 \mathrm{~s} / \mathrm{m}^{3}
\end{array}
$$

EXCEL Spreadsheets were set up to determine the relative air concentrations at the remaining distances. The calculations are performed in a similar manner but some of the tests resulted in different equations being used to arrive at the results.

\section{$\overline{\text { 3.0 Building Wake Effects and Plume Rise Verification }}$}

A simple building was analyzed along with the effects of plume rise for this hand calculation. Many of the parameters were determined using an EXCEL spreadsheet as shown in Figure A2. Determination of all other parameters follows: 
Downwind Distance of $30 \mathrm{~m}$.

Plume Rise

For plume rise due to buoyancy, using the parameters shown in Figure A2 and since $\mathrm{F} 0 \leq 55$ and $\mathrm{X}<\mathrm{XSTR}$

$$
\Delta \mathrm{h}_{\mathrm{B}}=1.6 \frac{\mathrm{F}_{0}^{1 / 3} \mathrm{X}^{2 / 3}}{\mathrm{U}}=1.6 \frac{31.31^{1 / 3} 30^{2 / 3}}{4}=12.17 \mathrm{~m}
$$

For plume rise due to momentum,

$$
\mathrm{XTEST}=\frac{27.0 * \text { DHMOM }}{\mathrm{B} 1}=\frac{27.0 * 15.4}{10.4}=39.88 \mathrm{~m}
$$

Since $\mathrm{X}$ is less than XTEST

$$
\Delta h_{m}=\left(B 1 * X * D H M O M^{2}\right)^{1 / 3}=\left(10.4 * 30 * 15.40^{2}\right)^{1 / 3}=42.02 m
$$

For a ground level release with no downwash

$$
\Delta h=42.02+12.17=54.19 m
$$

Building Effects

Test to see if $0.9 R_{\text {total }}<X_{c}$

$0.9 * 12.6<30$ is true.

For this case $A=1.75$ and $B=0.25$.

\section{Using}

$\mathrm{X}_{\mathrm{r}}=\frac{1.75 * 20 \mathrm{~m}}{1+0.25(20 / 10)}$

$\mathrm{X}_{\mathrm{r}}=23.33 \mathrm{~m}$

For downwind distances less than the length of the building:

$$
\begin{aligned}
& Z=0.27 R-0.1 X \\
& \mathrm{Z}=0.27 * 12.6-0.1 * 20=1.4 \mathrm{~m} \\
& \mathrm{Z}=\mathrm{Z}+\mathrm{BHT}=10.0+1.4=11.4 \mathrm{~m}
\end{aligned}
$$


Figure A2. Parameters for Wake Effects and Plume Rise Verification

\begin{tabular}{|c|c|c|c|c|}
\hline \multirow{2}{*}{\multicolumn{5}{|c|}{ 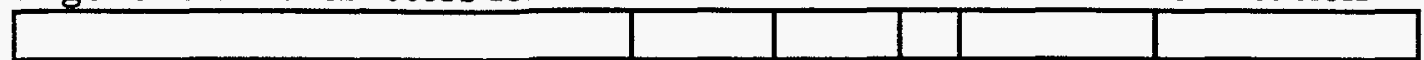 }} \\
\hline & & & & \\
\hline & & \multicolumn{3}{|c|}{ VENTSAR Verification } \\
\hline & & & & \\
\hline & & & & \\
\hline & & & & \\
\hline & & & & \\
\hline & & & & \\
\hline & & Units & & \\
\hline Release Location & A & & & \\
\hline$(A, C, D, F, H, K, P$, or $O$ for other $)$ & 0 & & & \\
\hline Grid Coordinates Easting & & $f t$ & & \\
\hline Northing & & $\mathrm{ft}$ & & \\
\hline Building Dimensions & & & & \\
\hline Building Height & 10 & $m$ & bmin & 10 \\
\hline Building Width & 20 & $m$ & bmax & 20 \\
\hline Building Length & 30 & $m$ & $\mathrm{ru}$ & 12.5992105 \\
\hline Penthouse Height & 0 & $m$ & pmin & 0 \\
\hline Penthouse Width & 0 & $m$ & pmax & 0 \\
\hline Penthouse Length & 0 & $m$ & rs & 0 \\
\hline Distance to Penthouse on Rooftop & 0 & $m$ & $r$ & 12.5992105 \\
\hline (Negative indicates on roof) & & & & \\
\hline Minimum Distance of interest & 10 & $\mathrm{Im}$ & delx & 0.99009901 \\
\hline Maximum Distance of Interest & 1010 & $m$ & & \\
\hline Number of Increments & 100 & & we & 63.662031 \\
\hline Compass Sector of Building & 3 & & b1 & 10.4254732 \\
\hline$(1-N, 2-N N E, \ldots)$ & & & dhmon & 15.398632 \\
\hline Distance of Vent from Roof Edge & -10 & $\mathrm{~m}$ & $\mathrm{MO}$ & 0.93610224 \\
\hline (negative is upwind) & & & & \\
\hline Vent Height & 0 & $\mathrm{~m}$ & & \\
\hline Radioactive Calculations(y or $n$ ) & & & & \\
\hline If yes Release Rate & 1 & $\mathrm{Ci} / \mathrm{mi}$ & & \\
\hline If No Mole Fraction of Vent Gas & 0 & & & \\
\hline Vent Gas Flow Rate & 0 & $\mathrm{~m} 3 / \mathrm{s}$ & & \\
\hline Averaging Option $(\mathrm{Y}$ or $\mathrm{N})$ & $\mathrm{N}$ & & ta & 293 \\
\hline If Yes Specify Probability Level & & & te & 313 \\
\hline If No Wind speed at Vent Height & 4 & m & usii & 4 \\
\hline \begin{tabular}{|l} 
Stability Class ( $1-7$ to $A-G)$ \\
\end{tabular} & C & & deli & -0.0682594 \\
\hline Plume Rise(Y or $\mathrm{N})$ & & & mwa & 28.96 \\
\hline Vent Diameter & 1 & $\mathrm{~m}$ & area & 0.7853975 \\
\hline Gas Molecular Weight & 78 & & we & 63.662031 \\
\hline Vent Gas Temperature & 40 & C & mwe & 28.96 \\
\hline Ambient Air Temperature & 20 & $\bar{C}$ & drho & 0.03194888 \\
\hline Use of Four Vent Heights ( $\mathrm{Y}$ or $\mathrm{N})$ & $Y$ & & FRI & 7.14856914 \\
\hline Enter Minimum Height & & $m$ & fo & 31.3099042 \\
\hline Increment Height & & $m$ & XSTR & 421.693752 \\
\hline
\end{tabular}


Now to determine the relative air concentration

$$
\frac{\chi}{Q}=\frac{1}{2 \pi \sigma_{y} \sigma_{z} U_{S}}\left[e^{-\left(\frac{\left(z-h_{s}\right)^{2}}{2 \sigma_{z}^{2}}\right)}+e^{-\left(\frac{\left(2+h_{s}\right)^{2}}{2 \sigma_{z}^{2}}\right)}\right]
$$

For $\mathrm{C}$ stability $30 \mathrm{~m}$ downwind of release location

$$
\begin{array}{ll}
\sigma_{\mathrm{y}}=\frac{\sigma_{\theta \mathrm{x}}}{1+0.031(\mathrm{x})^{0.46}} & \sigma_{\mathrm{z}}=0.06 \mathrm{x}(1+0.0002 \mathrm{x})^{-0.5} \\
\sigma_{\mathrm{y}}=\frac{0.305 * 30 \mathrm{~m}}{1+0.031(30)^{0.46}} & \sigma_{\mathrm{z}}=0.08 * 30 \mathrm{~m}(1+0.0002 * 30)^{-0.5} \\
\sigma_{\mathrm{y}}=7.98 \mathrm{~m} & \sigma_{\mathrm{z}}=2.39 \mathrm{~m}
\end{array}
$$

$\frac{\chi}{\mathrm{Q}}=\frac{\mathrm{e}^{-0.5((11.4-54.19) / 2.39)^{2}+\mathrm{e}^{-0.5((11.4+54.19) / 2.39)^{2}}}}{2^{*} 3.14^{*} 2.39 \mathrm{~m}^{*} 7.98 \mathrm{~m}^{*} 4 \mathrm{~m} / \mathrm{s}}=7.90 \mathrm{E}-73 \mathrm{~s} / \mathrm{m}^{3}$

For a downwind distance of $45 \mathrm{~m}$ which is just beyond the building, the calculations are shown below.

For plume rise due to buoyancy, using the parameters shown in Figure A2 and since Fo $\leq 55$ and $\mathrm{X} \leq \mathrm{XSTR}$

$$
\Delta \mathrm{h}_{\mathrm{B}}=1.6 \frac{\mathrm{F}_{0}^{1 / 3} \mathrm{X}^{2 / 3}}{\mathrm{U}}=1.6 \frac{31.31^{1 / 3} 45^{2 / 3}}{4}=15.95 \mathrm{~m}
$$

Since X $>$ XTEST

$\Delta \mathrm{h}_{\mathrm{m}}=3 \times \mathrm{DHMOM}=3 \times 15.4=46.2 \mathrm{~m}$

$\Delta \mathrm{h}=15.95 \mathrm{~m}+46.2 \mathrm{~m}=62.15 \mathrm{~m}$

Building Wake Effects

Since the point $\mathrm{X}$ is beyond the building, $\mathrm{Z}=0$.

Now to determine the relative air concentration 


$$
\frac{\chi}{Q}=\frac{1}{2 \pi \sigma_{y} \sigma_{z} U_{S}}\left[e^{-\left(\frac{\left(z-h_{s}\right)^{2}}{2 \sigma_{s}^{2}}\right)}+e^{-\left(\frac{\left(z+h_{c}\right)^{2}}{2 \sigma_{z}^{2}}\right)}\right]
$$

For $\mathrm{C}$ stability $45 \mathrm{~m}$ downwind of release location

$$
\begin{array}{ll}
\sigma_{\mathrm{y}}=\frac{\sigma_{\theta} \mathrm{x}}{1+0.031(\mathrm{x})^{0.46}} & \sigma_{\mathrm{z}}=0.06 \mathrm{x}(1+0.0002 \mathrm{x})^{-0.5} \\
\sigma_{\mathrm{y}}=\frac{0.305 * 45 \mathrm{~m}}{1+0.031(45)^{0.46}} & \sigma_{\mathrm{z}}=0.08^{*} 45 \mathrm{~m}(1+0.0002 * 45)^{-0.5} \\
\sigma_{\mathrm{y}}=11.66 \mathrm{~m} & \sigma_{\mathrm{z}}=3.58 \mathrm{~m}
\end{array}
$$

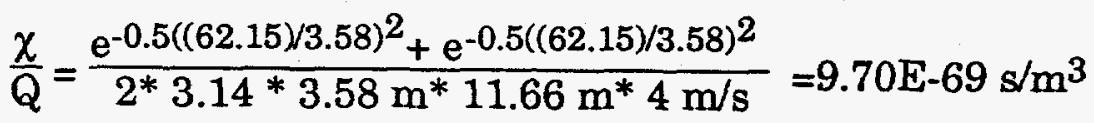

For a downwind distance of $100 \mathrm{~m}$.

For plume rise due to buoyancy, using the parameters shown in Figure A2 and since Fo $\leq 55$ and $\mathrm{X} \leq \mathrm{XSTR}$

$$
\Delta \mathrm{h}_{\mathrm{B}}=1.6 \frac{\mathrm{F}_{0}{ }^{1 / 3} \mathrm{X}^{2 / 3}}{\mathrm{U}}=1.6 \frac{31.31^{1 / 3} 100^{2 / 3}}{4}=27.16 \mathrm{~m}
$$

Since $X>X T E S T$

$$
\Delta \mathrm{h}_{\mathrm{m}}=3 \times \mathrm{DHMOM}=3 \times 15.4=46.2 \mathrm{~m}
$$

$$
\Delta \mathrm{h}=27.16 \mathrm{~m}+46.2 \mathrm{~m}=73.36 \mathrm{~m}
$$

Building Wake Effects

Since the point $\mathrm{X}$ is beyond the building, $\mathrm{Z}=0$.

Now to determine the relative air concentration

$$
\frac{\chi}{Q}=\frac{1}{2 \pi \sigma_{y} \sigma_{z} U_{S}}\left[e^{-\left(\frac{\left(z-h_{s}\right)^{2}}{2 \sigma_{z}^{2}}\right)}+e^{-\left(\frac{\left(z+h_{s}\right)^{2}}{2 \sigma_{z}^{2}}\right)}\right]
$$


For $\mathrm{C}$ stability $100 \mathrm{~m}$ downwind of release location

$$
\begin{aligned}
& \sigma_{\mathrm{y}}=\frac{\sigma_{\theta} \mathrm{x}}{1+0.031(\mathrm{x})^{0.46}} \quad \sigma_{\mathrm{z}}=0.06 \mathrm{x}(1+0.0002 \mathrm{x})^{-0.5} \\
& \sigma_{\mathrm{y}}=\frac{0.305 * 100 \mathrm{~m}}{1+0.031(100)^{0.46}} \quad \sigma_{\mathrm{z}}=0.08^{*} 100 \mathrm{~m}(1+0.0002 * 100)^{-0.5} \\
& \sigma_{\mathrm{y}}=24.28 \mathrm{~m} \quad \sigma_{\mathrm{z}}=7.92 \mathrm{~m} \\
& \frac{\chi}{\mathrm{Q}}=\frac{\mathrm{e}^{-0.5((73.36) / 7.92)^{2}}+\mathrm{e}^{-0.5((73.36) / 7.92)^{2}}}{2^{*} 3.14^{*} 7.92 \mathrm{~m}^{*} 24.28 \mathrm{~m}^{*} 4 \mathrm{~m} / \mathrm{s}}=9.85 \mathrm{E}-23 \mathrm{~s} / \mathrm{m}^{3}
\end{aligned}
$$

For a downwind distance of $500 \mathrm{~m}$.

For plume rise due to buoyancy, using the parameters shown in Figure A2 and since Fo $\leq 55$ and $X>X S T R$

$$
\Delta \mathrm{h}_{\mathrm{B}}=1.6 \frac{\mathrm{F}_{\mathrm{o}}{ }^{1 / 3} \mathrm{XSTR}^{2 / 3}}{\mathrm{U}}=1.6 \frac{31.31^{1 / 3} 421.69^{2 / 3}}{4}=70.90 \mathrm{~m}
$$

Since $X>X T E S T$

$$
\Delta h_{m}=3 \times D H M O M=3 \times 15.4=46.19 \mathrm{~m}
$$

$\Delta h=70.90 m+46.19 m=117.09 m$

Building Wake Effects

Since the point $\mathrm{X}$ is beyond the building, $\mathrm{Z}=0$.

Now to determine the relative air concentration

$$
\frac{\chi}{Q}=\frac{1}{2 \pi \sigma_{y} \sigma_{2} U_{S}}\left[e^{-\left(\frac{\left(z-h_{s}\right)^{2}}{2 \sigma_{s}^{2}}\right)}+e^{-\left(\frac{\left(z+h_{e}\right)^{2}}{2 \sigma_{s}^{2}}\right)}\right]
$$

For $\mathrm{C}$ stability $500 \mathrm{~m}$ downwind of release location

$$
\sigma_{\mathrm{y}}=\frac{\sigma_{\theta} \mathrm{x}}{1+0.031(\mathrm{x})^{0.46}} \quad \sigma_{\mathrm{z}}=0.06 \mathrm{x}(1+0.0002 \mathrm{x})^{-0.5}
$$




$$
\begin{array}{ll}
\sigma_{\mathrm{y}}=\frac{0.305 * 500 \mathrm{~m}}{1+0.031(500)^{0.46}} & \sigma_{\mathrm{z}}=0.08^{*} 500 \mathrm{~m}(1+0.0002 * 500)^{-0.5} \\
\sigma_{\mathrm{y}}=99.13 \mathrm{~m} & \sigma_{\mathrm{z}}=38.13 \mathrm{~m}
\end{array}
$$

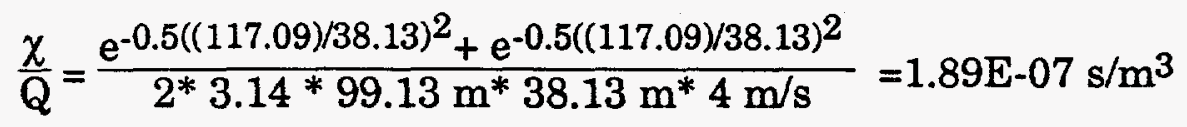

\subsection{Exceedance Probability Determination}

Verification of the pollutant concentration exceedance probability calculations was performed by setting up a Microsoft EXCEL Spreadsheet. Table 10 of the text shows the input parameters that were used for the calculation.

The following sheets show the Spreadsheet used for the calculations. These calculations are for a downwind distance of $200 \mathrm{~m}$. The first page shows the $\mathrm{K}$ Area meteorological data for certain sectors with the south sector appearing at the top of the first page. The second page shows the X/Q values that were determined for each of the 42 stability class and wind speed combinations along with their frequency of occurrence. The third page shows the ranking of these values in ascending order and the $X / Q$ value for meteorological conditions not exceeded $99.5 \%$ of the time which is determined by interpolation.

The annual average concentration are also calculated on the third page in the last column. The frequency and relative air concentration are multiplied for each of the 42 combinations and the results are summed to determine the annual average which is shown at the bottom of the page.

Similar calculations were performed for the remaining distances. 


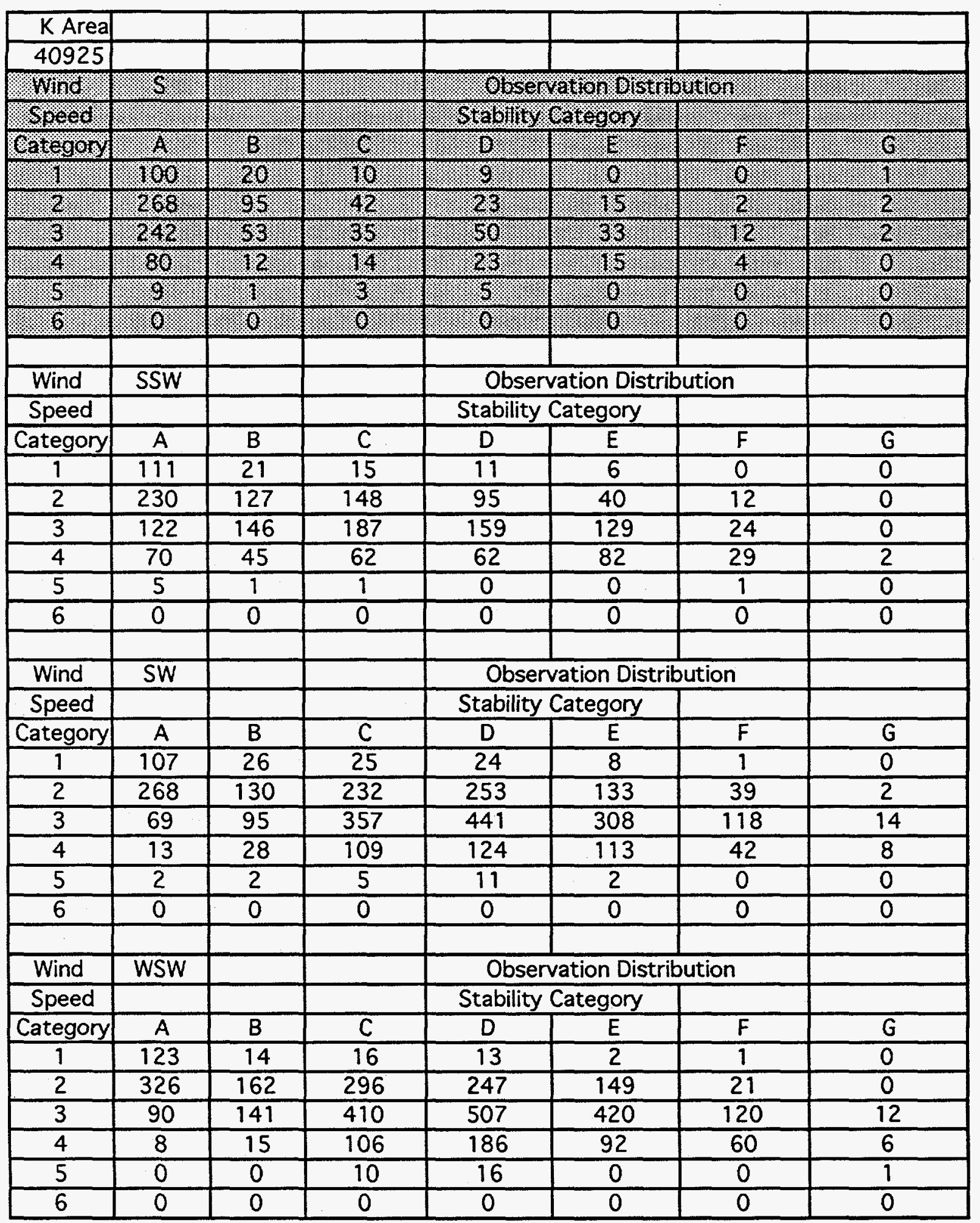




\begin{tabular}{|c|c|c|c|c|c|}
\hline DISTANCE (M) & 200 & South Sector & & & \\
\hline SECTOR & STABILITY & WINDSPEED & $X Q$ & FREQUENCY & \\
\hline 1] & 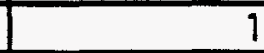 & 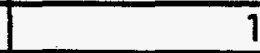 & $8.9174 \mathrm{E}-05$ & 0.00244349 & $2.179 \mathrm{E}-07$ \\
\hline 1 & 1 & 2 & $4.0563 \mathrm{E}-05$ & 0.00654856 & $2.6563 E-07$ \\
\hline 1 & $\overline{1}$ & $\overline{3}$ & $2.3167 \mathrm{E}-05$ & 0.00591326 & $1.3699 \mathrm{E}-07$ \\
\hline 1 & $\overline{1}$ & $\overline{4}$ & $1.7076 \mathrm{E}-05$ & 0.0019548 & $3.338 \mathrm{E}-08$ \\
\hline 1 & 1 & 5 & $1.2989 \mathrm{E}-05$ & 0.00021991 & $2.8566 \mathrm{E}-09$ \\
\hline 1 & 1 & $\overline{6}$ & & \multicolumn{2}{|c|}{$0 / 0$} \\
\hline 1 & $\overline{2}$ & 1 & 0.00017743 & 0.0004887 & $8.6708 \mathrm{E}-08$ \\
\hline 1 & $\overline{2}$ & $\overline{2}$ & $7.8383 \mathrm{E}-05$ & 0.00232132 & $1.8195 \mathrm{E}-07$ \\
\hline 1 & $\overline{2}$ & $\overline{3}$ & 4.8491E-05 & 0.00129505 & $6.2799 \mathrm{E}-08$ \\
\hline 1 & 2 & 4 & $3.5595 \mathrm{E}-05$ & 0.00029322 & $1.0437 E-08$ \\
\hline 1 & $\overline{2}$ & $\overline{5}$ & $2.7215 \mathrm{E}-05$ & $2.4435 \mathrm{E}-05$ & $6.65 \mathrm{E}-10$ \\
\hline 1 & 2 & 6 & & \multicolumn{2}{|c|}{$0 / 0$} \\
\hline 1 & 3 & 1 & 0.00029231 & 0.00024435 & $7.1425 E-08$ \\
\hline 1 & $\overline{3}$ & $\overline{2}$ & 0.00015522 & 0.00102627 & $1.593 \mathrm{E}-07$ \\
\hline 1 & $\overline{3}$ & $\overline{3}$ & 9.3199E-05 & 0.00085522 & $7.9706 \mathrm{E}-08$ \\
\hline 1 & 3 & 4 & $6.8516 \mathrm{E}-05$ & 0.00034209 & $2.3439 \mathrm{E}-08$ \\
\hline 1 & $\overline{3}$ & 5 & 4.7787E-05 & $7.3305 E-05$ & $3.503 E-09$ \\
\hline 1 & $\overline{3}$ & $\bar{\epsilon}$ & & \multicolumn{2}{|c|}{00} \\
\hline 1 & 4 & $\overline{1}$ & 0.00075763 & 0.00021991 & $1.6661 \mathrm{E}-07$ \\
\hline 1 & 4 & 2 & 0.00031005 & 0.000562 & $1.7425 \mathrm{E}-07$ \\
\hline 1 & 4 & 3 & 0.00020117 & 0.00122175 & $2.4578 \mathrm{E}-07$ \\
\hline 1 & 4 & 4 & 0.00014365 & 0.000562 & $8.0731 \mathrm{E}-08$ \\
\hline 1 & 4 & 5 & $9.8683 \mathrm{E}-05$ & 0.00012217 & $1.2057 \mathrm{E}-08$ \\
\hline 1 & 4 & $\bar{\epsilon}$ & & \multirow{2}{*}{\multicolumn{2}{|c|}{$\frac{0}{0} 0$}} \\
\hline 1 & 5 & 1 & & & \\
\hline 1 & 5 & 2 & 0.000839 & 0.00036652 & $3.0751 \mathrm{E}-07$ \\
\hline 1 & 5 & $\overline{3}$ & 0.00059659 & 0.00080635 & $4.8106 \mathrm{E}-07$ \\
\hline 1 & 5 & $\overline{4}$ & 0.00042316 & 0.00036652 & $1.551 \mathrm{E}-07$ \\
\hline 1 & 5 & 5 & & \multirow{2}{*}{\multicolumn{2}{|c|}{$\begin{array}{ll}0 \\
0\end{array}$}} \\
\hline 1 & 5 & 6 & ] & & \\
\hline 1 & 6 & 1 & 1] & \multicolumn{2}{|c|}{$0 / 0$} \\
\hline 1 & 6 & $\overline{2}$ & 0.00272938 & $4.887 \mathrm{E}-05$ & $1.3338 \mathrm{E}-07$ \\
\hline 1 & $\overline{6}$ & $\overline{3}$ & 0.00181959 & 0.00029322 & $5.3354 \mathrm{E}-07$ \\
\hline 1 & 6 & 4 & 0.00130945 & $9.774 \mathrm{E}-05$ & $1.2799 \mathrm{E}-07$ \\
\hline 1 & 6 & 5 & 5 & \multicolumn{2}{|c|}{$0 \mid 0$} \\
\hline 1 & 6 & $\bar{\epsilon}$ & 司 & \multicolumn{2}{|c|}{0,0} \\
\hline 1 & 7 & 1 & 0.02662812 & $2.4435 E-05$ & $6.5066 \mathrm{E}-07$ \\
\hline 1 & 7 & $\overline{2}$ & 0.01084523 & $4.887 \mathrm{E}-05$ & $5.3001 E-07$ \\
\hline 1 & 7 & 3 & 0.00693911 & $4.887 \mathrm{E}-05$ & $3.3911 \mathrm{E}-07$ \\
\hline 1 & 7 & 2 & 70 & 0 & 0 \\
\hline 1 & $\overline{7}$ & 5 & 可 & \multicolumn{2}{|c|}{$0 \longdiv { 0 }$} \\
\hline 1 & 7 & $\bar{\epsilon}$ & 可 & \multicolumn{2}{|c|}{010} \\
\hline & & & & & $5.2745 E-06$ \\
\hline
\end{tabular}




\begin{tabular}{|c|c|c|c|c|c|c|}
\hline Dist & 200 & & & & & \\
\hline \begin{tabular}{|l|} 
STAB \\
\end{tabular} & WS & $\mathrm{X} / \mathrm{Q}$ & FREQUENCY & Cum Freq & & \\
\hline $\begin{array}{l}1 \\
\end{array}$ & $\overline{6}$ & & 年 & 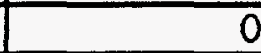 & & 0 \\
\hline 2 & $\overline{6}$ & & $\overline{0}$ & 0 & & $\sqrt{0}$ \\
\hline 3 & 6 & & 0 & 0 & & 0 \\
\hline 4 & $\overline{6}$ & & 0 & $\overline{0}$ & & 0 \\
\hline 5 & 1 & & 0 & 0 & & 0 \\
\hline 5 & 5 & & 0 & 0 & & 0 \\
\hline 5 & $\overline{6}$ & & $\overline{0}$ & $\overline{0}$ & & 0 \\
\hline 6 & 1 & & 0 & 0 & & 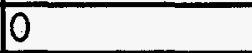 \\
\hline 6 & $\overline{5}$ & & $\overline{0}$ & $\overline{0}$ & & 0 \\
\hline 6 & 6 & & 0 & 0 & & 0 \\
\hline 7 & 4 & & 0 & 0 & & 0 \\
\hline 7 & $\overline{5}$ & & 0 & 0 & & 0 \\
\hline 7 & $\overline{6}$ & & $\overline{0}$ & $\overline{0}$ & & 0 \\
\hline 7 & 1 & 0.02662812 & $2.4435 \mathrm{E}-05$ & $2.4435 E-05$ & & $6.5066 \mathrm{E}-07$ \\
\hline 7 & 2 & 0.01084523 & $4.887 E-05$ & $7.3305 E-05$ & & $5.3001 \mathrm{E}-07$ \\
\hline 7 & $\overline{3}$ & 0.00693911 & $4.887 \mathrm{E}-05$ & 0.00012217 & & $3.3911 \mathrm{E}-07$ \\
\hline 6 & 2 & 0.00272938 & $4.887 \mathrm{E}-05$ & 0.00017104 & & $1.3338 \mathrm{E}-07$ \\
\hline 6 & 3 & 0.00181959 & 0.00029322 & 0.00046426 & & $5.3354 \mathrm{E}-07$ \\
\hline 6 & 4 & 0.00130945 & $9.774 \mathrm{E}-05$ & 0.000562 & & $1.2799 \mathrm{E}-07$ \\
\hline 5 & $\overline{2}$ & 0.000839 & 0.00036652 & 0.00092853 & & $3.0751 \mathrm{E}-07$ \\
\hline 4 & 1 & 0.00075763 & 0.00021991 & 0.00114844 & & $1.6661 \mathrm{E}-07$ \\
\hline 5 & 3 & 0.00059659 & 0.00080635 & 0.0019548 & & $4.8106 \mathrm{E}-07$ \\
\hline 5 & 4 & 0.00042316 & 0.00036652 & 0.00232132 & & $1.551 \mathrm{E}-07$ \\
\hline 4 & 2 & 0.00031005 & 0.000562 & 0.00288332 & & $1.7425 \mathrm{E}-07$ \\
\hline 3 & 1 & 0.00029231 & 0.00024435 & 0.00312767 & & $7.1425 \mathrm{E}-08$ \\
\hline 4 & 3 & 0.00020117 & 0.00122175 & 0.00434942 & & $2.4578 \mathrm{E}-07$ \\
\hline 2 & $\overline{1}$ & 0.00017743 & 0.0004887 & 0.00483812 & 000017392 & $8.6708 \mathrm{E}-08$ \\
\hline 3 & 2 & 0.00015522 & 0.00102627 & 0.00586439 & & $1.593 \mathrm{E}-07$ \\
\hline 4 & $\overline{4}$ & 0.00014365 & 0.000562 & 0.00642639 & & $8.0731 \mathrm{E}-08$ \\
\hline 4 & 5 & $9.8683 \mathrm{E}-05$ & 0.00012217 & 0.00654856 & & $1.2057 \mathrm{E}-08$ \\
\hline 3 & $\overline{3}$ & $9.3199 \mathrm{E}-05$ & 0.00085522 & 0.00740379 & & $7.9706 \mathrm{E}-08$ \\
\hline 1 & 7 & $8.9174 \mathrm{E}-05$ & 0.00244349 & 0.00984728 & & $2.179 \mathrm{E}-07$ \\
\hline 2 & 2 & $7.8383 \mathrm{E}-05$ & 0.00232132 & 0.0121686 & & $1.8195 \mathrm{E}-07$ \\
\hline 3 & 4 & $6.8516 \mathrm{E}-05$ & 0.00034209 & 0.01251069 & & $2.3439 \mathrm{E}-08$ \\
\hline 2 & $\overline{3}$ & $4.8491 \mathrm{E}-05$ & 0.00129505 & 0.01380574 & & $6.2799 \mathrm{E}-08$ \\
\hline 3 & 5 & $4.7787 \mathrm{E}-05$ & $7.3305 \mathrm{E}-05$ & 0.01387905 & & $3.503 E-09$ \\
\hline 1 & 2 & $4.0563 \mathrm{E}-05$ & 0.00654856 & 0.02042761 & & $2.6563 \mathrm{E}-07$ \\
\hline 2 & 4 & $3.5595 \mathrm{E}-05$ & 0.00029322 & 0.02072083 & & $1.0437 \mathrm{E}-08$ \\
\hline 2 & $\overline{5}$ & $2.7215 \mathrm{E}-05$ & $2.4435 \mathrm{E}-05$ & 0.02074527 & & $6.65 \mathrm{E}-10$ \\
\hline 1 & 3 & $2.3167 \mathrm{E}-05$ & 0.00591326 & 0.02665852 & & $1.3699 \mathrm{E}-07$ \\
\hline 1 & 4 & $1.7076 \mathrm{E}-05$ & 0.0019548 & 0.02861332 & & $3.338 \mathrm{E}-08$ \\
\hline 1 & 5 & $1.2989 E-05$ & 0.00021991 & 0.02883323 & & $2.8566 \mathrm{E}-09$ \\
\hline & & & & & Annual Ave & $5.2745 E 06$ \\
\hline
\end{tabular}




\section{VERIFICATION OF VENTSAR(U)}

\section{DISTRIBUTION (16)}

R. P. Addis, 773-A

A. L. Boni, 773-A

W. H. Carlton, 773-A

J. M. East, 992-1W

G.T. Jannik, 773-A

K. R. O'Kula, 992-1W

L. M. Papouchado, 773-A

A. A. Simpkins, 773-A

A.H. Weber, 773-A

SRTCRecords (4).7.7. $52 \mathrm{~A}$

ED G Records(5), 773-A 